\title{
Bosminopsis deitersi (Crustacea: Cladocera) as an ancient species group: a revision
}

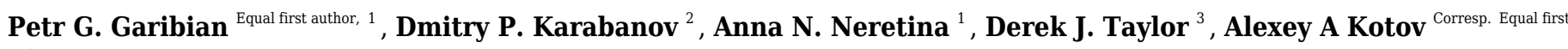 \\ author, 1 \\ ${ }^{1}$ Laboratory of Aquatic Ecology and Invasions, A.N. Severtsov Institute of Ecology and Evolution of Russian Academy of Sciences, Moscow, Russia \\ 2 Laboratory of Fish Ecology, I.D. Papanin Institute for Biology of Inland Waters of Russian Academy of Sciences, Borok, Yaroslavl Area, Russia \\ 3 Department of Biological Sciences, The State University of New York at Buffalo, Buffalo, New York, United States \\ Corresponding Author: Alexey A Kotov \\ Email address: alexey-a-kotov@yandex.ru
}

Water fleas (Crustacea: Cladocera) of the Family Bosminidae have been studied since the founding of paleolimnology and freshwater ecology. However, one species, Bosminopsis deitersi, stands out for its exceptional multicontinental range and broad ecological requirements. Here we use an integrated morphological and multilocus genetic approach to address the species problem in $B$. deitersi. We analyzed 32 populations of $B$. deitersi $\mathrm{s}$. lat. Two nuclear and two mitochondrial loci were used to carry out the bGMYC, mPTP and STACEY algorithms for species delimitation. Detailed morphological study was also carried out across continents. The evidence indicated a widely distributed cryptic species in the Old World (Bosminopsis zernowi) that is genetically divergent from B. deitersi s.str. We revised the taxonomy and redescribed the species in this complex. Our sampling indicated that $B$. zernowi had weak genetic differentiation across its range. A molecular clock and biogeographic analysis with fossil calibrations suggested a Mesozoic origin for the Bosminopsis deitersi group. Our evidence rejects the single species hypothesis for $B$. deitersi and is consistent with an ancient species group (potentially Mesozoic) that shows marked morphological conservation. The family Bosminidae, then, has examples of both rapid morphological evolution (Holocene Bosmina), and morphological stasis (Bosminopsis). 
1

4 Petr G. Garibian ${ }^{1 *}$, Dmitry P. Karabanov ${ }^{2}$, Anna N. Neretina ${ }^{1}$, Derek J. Taylor ${ }^{3}$ and Alexey A.

$5 \operatorname{Kotov}^{1 *}$

6

$7 \quad{ }^{1}$ Laboratory of Aquatic Ecology and Invasions, A.N. Severtsov Institute of Ecology and

8 Evolution of Russian Academy of Sciences, Moscow, Russia.

$9 \quad{ }^{2}$ Laboratory of Fish Ecology, I.D. Papanin Institute for Biology of Inland Waters of Russian

10 Academy of Sciences, Borok, Yaroslavl Area, Russia.

11

12

13

14

15

16

17

18

19

20

21

22

\section{ancient species group: a revision}

${ }^{3}$ Department of Biological Sciences, The State University of New York at Buffalo, Buffalo, USA.

* Equal first authors

6 Corresponding author: Alexey A. Kotov ${ }^{1}$

17 Leninsky prospect 33, Moscow, 119071, Russia

8 alexey-a-kotov@yandex.ru 
Water fleas (Crustacea: Cladocera) of the Family Bosminidae have been studied since the

24

founding of paleolimnology and freshwater ecology. However, one species, Bosminopsis

deitersi, stands out for its exceptional multicontinental range and broad ecological requirements.

Here we use an integrated morphological and multilocus genetic approach to address the species problem in $B$. deitersi. We analyzed 32 populations of $B$. deitersi s. lat. Two nuclear and two mitochondrial loci were used to carry out the bGMYC, MPTP and STACEY algorithms for species delimitation. Detailed morphological study was also carried out across continents. The evidence indicated a widely distributed cryptic species in the Old World (Bosminopsis zernowi) that is genetically divergent from $B$. deitersi s.str. We revised the taxonomy and redescribed the species in this complex. Our sampling indicated that B. zernowi had weak genetic differentiation across its range. A molecular clock and biogeographic analysis with fossil calibrations suggested a Mesozoic origin for the Bosminopsis deitersi group. Our evidence rejects the single species hypothesis for $B$. deitersi and is consistent with an ancient species group (potentially Mesozoic) that shows marked morphological conservation. The family Bosminidae, then, has examples of both rapid morphological evolution (Holocene Bosmina), and morphological stasis (Bosminopsis).

Keywords: Phylogeography, Phylogeny, Molecular clock, Taxonomy, Cladocera, Eurasia Running title: Bosminopsis deitersi as an ancient group

\section{Introduction}


46

47

on paleolimnological records from the Quaternary. He later based the paradigm of "noncosmopolitanism" (Frey, 1982, 1987b) on this apparent long-term stability in morphology. According to non-cosmopolitanism, geographic differentiation occurred mainly due to vicariant events related to the disruption of Pangaea and the dispersal barriers imparted by subsequent continental drift. The process (often termed "continental endemism") now has strong support among "traditional" taxonomists (Van Damme \& Kotov, 2016; Smirnov \& Kotov, 2018; Neretina, Kotov \& Van Damme, 2019) and molecular ecologists (Xu et al., 2009; Heads, 2012). Frey's early insights on non-cosmopolitanism made the Cladocera (Frey, 1982, 1987a) a model group for freshwater animals. However, a transcontinental distribution for many freshwater taxa persists. One of these species reported from many continents is Bosminopsis deitersi Richard, 1895 (Cladocera: Bosminidae). After the first description of $B$. deitersi from La Plata (Richard, 1895), the species was found in many tropical (Daday, 1903; Brehm, 1913, 1939; Rahm, 1956; Dumont, 1981; Idris, 1983; Collado, Fernando \& Sephton, 1984; Dumont, 1986; Tanaka \& Ohtaka, 2010; Korovchinsky, 2013; Kotov et al., 2013) and temperate (Linko, 1901; Birge, 1918; Ueno, 1932; Pirozhnikov, 1937; Ueno, 1937a; Ueno, 1937b, 1940; Tanaka, 2000; Jeong, Kotov \& Lee, 2014; Beaver et al., 2018) regions. Citing minor morphological differences from B. deitersi (see checklist below), several authors described regional taxa. Bosminopsis zernowi Linko, 1901, found in European Russia, was the second taxon to be named in this group. Burckhardt (Burckhardt, 1909) concluded that there are three alternative views of the group's diversity: 1) at least eight local forms ("Lokalväriataten"), 2) multiple independent species, and 3) a single broadly distributed taxon, $B$. deitersi. Later he advocated 11 extant "taxa" in the group (Burckhardt, 1924).

Burckhardt's view failed to gain support, with most authors recognizing that Bosminopsis 
69 is a monotypic genus (Krasnodebski, 1937; Ueno, 1937a; Ueno, 1937b; Chiang \& Du, 1979;

70 Yoon, 2010). Behning (Behning, 1941) and Manujlova (Manujlova) regarded some forms

71 described by Burckhardt as regional subspecies but gave very obscure diagnoses. At the end of

72 the 20th century, researchers of tropical populations (Frey, 1982; Smirnov \& Timms, 1983;

73 Michael \& Sharma, 1988; Smirnov, 1995; Sanoamuang, 1997) also assigned specimens to a

74 single taxon, B. deitersi. Indeed, Kořínek (Korinek, 1984) directly stated that "Bosminopsis

75 deitersi was regarded as the only species within the genus". However, in the last third of the 20th

76 century, two species of Bosminopsis beyond the B. deitersi group were found in the Amazon

77 River basin (Brandorff, 1976; Rey \& Vasquez, 1989).

B. deitersi, as presently described, has an unusually broad biogeographic range and ecological preference for a cladoceran species. Wolsky (Wolski, 1932) wrote that Bosminopsis deitersi prefers "warm water". However, Pirozhnikov (Pirozhnikov, 1937) detected Bosminopsis in high latitude waters of the $\mathrm{Ob}$ and Yenisei river deltas. Kotov (Kotov, 1997b) suggested that these North Eurasian populations belong to a separate taxon from B. deitersi, B. zernowi Linko, 1900.

An integrated approach, which combines molecular phylogeny, phylogeography, formal

biogeography, and morphological analysis has advanced the taxonomy of several difficult groups (Dayrat, 2005; Padial \& La Riva, 2010). Here we use an integrated approach to address the taxonomy of the $B$. deitersi group. We find evidence that the group contains several related species with modest geographic ranges and weak morphological differentiation. We reconstruct this group's evolutionary history and provide evidence for the antiquity and morphological conservation of the genus Bosminopsis. We also redescribe $B$. deitersi and $B$. zernowi and analyze their synonyms. 
92

93

94

95

96

97

\section{Materials \& Methods}

\section{Ethic statement}

Field collection in public property in Russia does not require permissions. Samples in South Korea were collected in the frame of cooperation between A.A. Kotov and the National Institute of Biological Resources of Korea and does not require special permission. The sample from Arkansas, USA was obtained from collections resulting from a previous NSF grant. The samples from Japan, China, and Thailand were provided by our colleagues having permissions to collect them due to their scientific activity in the governmental institutes in the corresponding countries. Formalin samples from Brazil were kept in the Collection of Zoological Museum of Moscow State University for a long time, they were collected before the time when Brazil introduced very strict regulations for sampling. The species were not assessed as endangered at the time of collection and are currently not subject to specific regulations, however all efforts were taken to ensure that the collection and preservation of animals was performed with due consideration of their welfare. The number of individuals taken did not represent a significant proportion of the population present at each site.

\section{Sample collection and morphological analyses}

Samples from different localities were collected via small-sized plankton nets (with mesh size $50 \mu \mathrm{m}$ ) and fixed via $4 \%$ formaldehyde or $96 \%$ ethanol in the fields, using conventional techniques. All samples were initially examined using a stereoscopic microscope LOMO. Individuals of Bosminopsis were initially identified via available references using morphological 
115 features (Kotov, 1997a, 1997b; Rogers et al., 2019). Existing museum samples were used for 116 morphological analysis (see the list of material in Supplementary Table S1).

117 The morphology of populations from the Neotropics and the Palaearctic was examined in

118 detail to assess the presence of taxonomically significant characters. Specimens of Bosminopsis

119 from presorted formalin and alcohol samples were selected under a binocular stereoscopic

120 microscope LOMO. They were then studied in toto under optical microscopes (Olympus BX41

121 or Olympus CX 41) in a drop of glycerol formaldehyde or a glycerol-ethanol mixture. Then, at

122 least two parthenogenetic females, two ephippial females, and two males (if available) from each

123 locality were dissected under a stereoscopic microscope for appendages and postabdomens.

124 Drawings were prepared using a camera lucida attached to the optical microscopes.

125 Some individuals from Neotropical and Palaearctic localities were dehydrated in an ethanol

126 series $(30,50,70,95 \%)$ and $100 \%$ acetone and then dried from hexametyldisilazane. Dried

127 specimens were mounted on aluminum stubs, coated by gold in S150A Sputter Coater (Edwards,

128 United Kingdom), and examined under a scanning electron microscope (Vega 3 Tescan

129 Scanning Electron Microscope, TESCAN, Czech Republic).

130

DNA extraction, amplification and sequencing

Only alcohol samples were used for the genetic analysis. Each specimen was accurately

134 from single adult females using the Wizard Genomic DNA Purification Kit (Promega Corp., 135 Madison, WI) and QuickExtract DNA Extraction Solution (Epicentre by part Illumina, Inc.,

136 Madison, WI) using manufacturer's protocols. Two mitochondrial and two nuclear markers were

137 investigated here: (1) the 5'-fragment of the first subunit of mitochondrial cytochrome oxidase 
$138(C O I)$ - a protein-coding marker widely used in DNA barcoding (Hebert et al., 2003); (2) the 5'-

139 fragment of the mitochondrial $16 \mathrm{~S}$ rRNA gene (16S) with a mosaic of highly conservative

140 duplexes and variable loops (Yang et al., 2014); and (3-4) 5'-fragments of the nuclear ribosomal

141 genes ( $18 S$ rRNA and $28 S$ rRNA). Each fragment contains both long conservative portions and

142 two variable domains. Although these nuclear markers are predominantly used for divergent taxa

143 (Hovmoller, Pape \& Kallersjo, 2002), they are informative at the species level for many

144 microcrustaceans (Karabanov et al., 2018).

145 Primers used for amplification are listed in Table 4. Polymerase chain reactions (PCR)

146 were carried out in a total volume of $20 \mu \mathrm{l}$, consisting of $2 \mu \mathrm{l}$ of genomic DNA solution, $1 \mu 1$ of

147 each primer $(10 \mathrm{mM}), 6 \mu \mathrm{l}$ of double-distilled $\mathrm{H}_{2} \mathrm{O}$ and $10 \mu \mathrm{l}$ of ready-to-use PCR Master Mix

148 2X solution (Promega Corp., Madison, WI). PCR products were visualized in a 1.5\% agarose gel

149 stained with ethidium bromide and purified by QIAquick Spin Columns (Qiagen Inc., Valencia,

$150 \mathrm{CA}$ ). The PCR program included a pre-heating of 3 min at $94^{\circ} \mathrm{C}$; 40 cycles (initial denaturation

151 of $30 \mathrm{sec}$ at $94^{\circ} \mathrm{C}$, annealing of $40 \mathrm{sec}$ at a specific temperature, an extension of $80 \mathrm{sec}$ at $72^{\circ} \mathrm{C}$ );

152 and a final extension of 5 min at $72^{\circ} \mathrm{C}$ (Table 4). Each PCR product was sequenced bi-

153 directionally on an ABI 3730 DNA Analyzer (Applied Biosystems) using the ABI PRISM

154 BigDye Terminator v.3.1 kit at the Syntol Co, Moscow. The authenticity of the sequences was

155 verified by BLAST comparisons with published cladoceran sequences in mBLAST (Boratyn et 156 al., 2013).

157 The sequences from this study were submitted to the NCBI GenBank database for 16S acc. no. MT757174-MT757231, for COI acc. no. MT757459-MT757473, for 18S acc. no. 
161

162

163

164

165

166

167

168

169

170

171

172

173

174

175

176

177

178

179

180

181

182

183

\section{Population analysis, alignment and phylogenetic analysis}

Alignment of sequences from each locus was carried out using the MAFFT v.7 algorithm (Katoh, Rozewicki \& Yamada, 2019) available on the server of the Computational Biology

Research Center, Japan (http://mafft.cbrc.jp). For the protein-coding gene COI, we used the "Translation Align" option with the FFT-NS-i strategy. For alignment of the ribosomal-coding

loci, we used the Q-INS-i strategy (secondary structure is considered by this algorithm). Linking sequences and their partitioning for subsequent analyses were made in SequenceMatrix v.1.8 (Vaidya, Lohman \& Meier, 2011).

Nucleotide diversity analysis (Nei \& Kumar, 2000) and neutrality tests were carried out using DnaSP v.6.12 (Rozas et al., 2017). We applied the Fs (Fu, 1997) and D (Tajima, 1989) tests to confirm neutrality and describe demographic processes in Bosminopsis population (Ramirez-Soriano et al., 2008; Garrigan, Lewontin \& Wakeley, 2010). To determine the most probable demographic model for Bosminopsis sequences, we performed a coalescent simulation for each locus (1000 replications) in DnaSP v.6.12 (Rozas et al., 2017) using five demographic models (Standard Neutral Model, Population Growth, Population Decline, Population Bottleneck, Population Split/Admixture). The best model was selected based on the Theta-W (theta with Watterson) estimator (Watterson, 1975; Nei \& Kumar, 2000).

The best-fitting models of the nucleotide substitutions for each locus and for linked data were selected using ModelFinder v.1.6 (Kalyaanamoorthy et al., 2017) at the Center for Integrative Bioinformatics Vienna web-portal, Austria (http://www.iqtree.org) (Trifinopoulos et al., 2016) based on minimal values of the Bayesian information criteria (BIC) (Schwarz, 1978). The BIC model parameters were almost identical to those obtained using the corrected Akaike's information criterion, AICc. 
For the COI locus, the substitution model was partitioned by the nucleotide position of

185

186

187

188

189

190

191

192

193

194

195

196

197

198

199

200

201

202

203

204

205

206

codons (1st, 2nd, 3rd). We used the multi-taxon coalescence model "star" in BEAST2 (Heled \&

Drummond, 2010) with partitioned models (Chernomor, Haeseler \& Minh, 2016). Phylogenetic

reconstructions based on the maximum likelihood (ML) and Bayesian (BI) methods were made

for each gene separately, the full set of mitochondrial genes, the full set of nuclear genes, and for all "unlinked" genetic data. We included sequences with incomplete or missing data as exclusion can reduce the accuracy of phylogenetic reconstruction (Molloy \& Warnow, 2018).

We used the IQ-TREE v.1.6.9 algorithm (Nguyen et al., 2015) via a web-portal CIBIV, Austria for ML tree estimation. Each set of sequences was analysed based on the best model found automatically by the W-IQ-TREE (Trifinopoulos et al., 2016). To estimate the branch support values, we used UFboot2 (Hoang et al., 2018). The Topology of the ML trees was evaluated based on PhyML SH-like tests (Shimodaira, 2002), performed in the block Building Phylogenetic Tree in uGENE v.34 (Okonechnikov, Golosova \& Fursov, 2012). BI analysis was performed in BEAST2 v.2.6.2 (Bouckaert et al., 2019), with all of the parameters of the substitution model using the BIC criterion from BEAUti v.2.5.2 (Drummond et al., 2012). In each analysis, we conducted four independent runs of MCMC (40M generations and a sampling interval of 10k generations), with effectiveness control in Tracer v.1.7 (Rambaut et al., 2018). A consensus tree based on the maximum clade credibility (MCC) was obtained in TreeAnnotator v.2.5.2 (Drummond et al., 2012) with a burn-in of at least $20 \%$. Because the main clades for BI and ML were congruent, we presented the BI trees, with ML branch support/ BI posterior probabilities for key nodes.

A haplotype network was constructed for Bosminopsis zernowi (the most sampled taxon in this study) in popART v.1.7 with the Integer Neighbor-Joining Network algorithm (Leigh, 
207 Bryant \& Nakagawa, 2015) and minimal reticulation tolerance.

208

209

Cybertaxonomic species delimitation based on DNA data

210 Our approach to cybertaxonomic taxon delimitation was described in a previous paper

211 (Kotov et al., 2021). An integrated approach based on genetic species delimitation combined with

212 "traditional" morphological taxonomy was used to estimate the species richness. We used the

213 bGMYC, mPTP and STACEY algorithms for species delimitation (Carstens et al., 2013).

214 The general mixed Yule-coalescent model (GMYC) was made to assign analyzed

215 individuals to the species according to ultrametric time trees derived from single-locus data

216 (Pons et al., 2006). But the "classical" GMYC has limitations (Lohse, 2009). We used the

217 Bayesian GMYC model in the 'bGMYC' package (Reid \& Carstens, 2012) for the statistical

218 language "Microsoft R-Open and MKL" 64-bit v.3.5.3 (http://mran.microsoft.com). Ultrametric

219 trees for each mitochondrial and nuclear datasets were evaluated in BEAST2. For MCMC, we

220 used 50M generations with a sampling interval of 50k trees. We used Tracer v.1.7 to evaluate the

221 convergence of parameters (based on ESS $>200$ ). Sequences of Triops and Bosmina were used as

222 outgroups. Sorting, re-rooting of the trees and outgroup deletion was carried out in "R"

223 according to the script of Sweet et al. (2018). For the bGMYC analysis, we randomly selected

224100 ultrametric trees from the 1000 trees after burn-in from BEAST2. The results were accepted

225 as statistically significant at a modified $\mathrm{P}>0.99$ level.

226 Analysis of Multi-rate Poisson Tree Processes (mPTP) (Kapli et al., 2017) was performed

227 on the web-server of Heidelberg Institute for Theoretical Studies (http://mptp.h-its.org/). As the

228 input trees, we used the phylogenetic BI trees from BEAST2 and the ML-tree obtained using W-

229 IQ-TREE for each locus. Delimitation results were congruent for separate loci and were 
230

231

232

233

234

235

236

237

238

239

240

241

242

243

244

245

246

247

248

249

250

251

252

composed of mitochondrial and nuclear datasets.

The combined species tree estimation and species delimitation analysis for STACEY (Species Tree And Classification Estimation, Yarely) (Jones, 2017), was made in BEAST2. Genealogical relationships were estimated by STACEY with four independent generations (50M generations of $\mathrm{MCMC}$, sampling of every 10k generation) after incorporating the suggestions from an initial run. STACEY log files were examined with Tracer v.1.7 to evaluate the convergence of parameters based on ESS $>400$. Supports for the tree topologies estimated by STACEY were examined by constructing a maximum clade credibility tree using TreeAnnotator v2.6 (part of the BEAST2) after discarding half of all estimated trees. Species delimitations based on the trees estimated by STACEY were assessed using the Jones' java-application speciesDA http://www.indriid.com/software.html.

\section{Phylogenetic reconstruction and molecular clock}

Two approaches were used for molecular clock estimation. A strict molecular clock Место для ввода текста. was based on the assumption of a relatively regular mutation rate in mitochondrial genes. The speed of mutation accumulation differs among organisms. For the crustaceans the rate is ca. $0.11-2.4 \%$ per MYA (Knowlton \& Weigt, 1998; Schubart, Diesel \& Hedges, 1998; Schwentner et al., 2013; Bekker et al., 2018). Apparently this is a very rough estimation (Schwartz \& Maresca, 2006). An alternative approach uses paleontological data to calibrate "molecular clocks".

To estimate the probability of molecular clock-like data, we applied a Maximum Likelihood method implemented in MEGA-X v.10.1.8 (Kumar et al., 2018). A Maximum Likelihood substitution model was estimated for each locus (separately for each nucleotide 
253 position for translated genes, and jointly for non-translated fragments). We used the best model

254 as selected by the lowest BIC (Bayesian Information Criterion) scores and an ML tree with

255 Bosmina as the outgroup.

256 For determination of the relative rate of substitutions, we used both paleontological

257 information (Kotov \& Taylor, 2011) and points based on molecular phylogenetic data

258 (Schwentner et al., 2013). As calibration points (with 15\% standard deviations), we used the

259 following estimates: Triops/ all groups 340 MYA, Daphnia/ Simocephalus 145 MYA,

260 Cyclestheria groups 120-70 MYA, and Bosmina / Bosminopsis without an exact date. The age of

261 lineage differentiation according to a strict molecular clock model was estimated in BEAST

262 v.1.10.4 (Suchard et al., 2018) with a Yule speciation model as the most proper for datasets with

263 several potential species (Gernhard, 2008). Four independent runs of 50M generations were

264 done, with each 100k tree sampled. Subsequent analysis was performed as above for BI

265 following the recommendations (Barido-Sottani et al., 2018).

266

267

\section{Phylogeographic reconstructions}

To test phylogeographic models, we used the packet BioGeoBEARS (Matzke, 2013) with

the integrated statistical package of the "R" language in RASP4 v.4.2 (Yu et al., 2015). The data set was composed based on the maximum number of geographic localities and representation of all phylogenetic lineages revealed by cybertaxonomic methods. We estimated a mitochondrial

272 phylogenetic tree based on sequences of two genes (COI and 16S) for Bosminopsis cf. deitersi.

273 Objective software limitations allowed us to analyze only 27 sequences from five phylogenetic

274 lineages and seven main geographic regions.

275 We tested six biogeographic models in BioGeoBEARS (standard dispersion-vicariant, and 
276 those with a correction for speciation events $+\mathrm{J}$ ), estimated according to the AICc_wt criterion

277 (Matzke, 2014). A phylogeny for RASP4 was reconstructed in BEAST2. In each analysis, we

278 conducted four independent runs of MCMC (40M generations, with a sampling interval of 10k

279 generation). The best model according to the maximum AICc_wt value was DIVALIKE+J,

280 which takes into consideration new lineage origin upon colonization by a founder without the

281 existence of a widely distributed ancestor (Clark et al., 2008). For estimates of the age of

282 historical processes, we used an outgroup "calibration". Palaeoreconstruction was performed in

283 GPlates v.2.2 (Muller et al., 2018) with PALEOMAP PaleoAtlas v.3 by Christopher R. Scotese

284 (https://www.earthbyte.org/paleomap-paleoatlas-for-gplates).

285

$286 \quad$ Abbreviations

287

288

Abbreviations for collections

289

MGU ML - collection of Zoological Museum of Moscow State University.

290

291

292

293

exopodite; ejh - ejector hooks on limb I; epp - epipodite; ext - exopodite; fpl - filter plate of

294

gnathobase; lat - lateral setae of exopodite; mxp - maxillar process of limb I; odl - outer distal

lobe of limb I; pep - preepipodite; pos - posterior setae; sdl - inner subdistal lobe of limb I.

296

297

Results 


\section{Phylogenetics and phylogeography}

We analyzed 118 specimens from 32 populations belonging to the $B$. deitersi group. The specimens originated mainly from Eurasia (Fig. 1), but a single population from North America and a single population from South America were also analyzed (Supplementary Table S1).

We obtained 58 original sequences of $16 S, 15$ sequences of $C O I, 43$ sequences of $18 S$, and 75 sequences of $28 S$. Populations had a relatively high genetic polymorphism (Table 1). In contrast, the number of haplotypes was small. Each locus had a differing optimal substitution model (Supplementary Table S2).

Three major clades of the Bosminopsis deitersi group were revealed from a tree based on the mitochondrial dataset (Supplementary Figure 1A). The first clade was B. zernowi - widely distributed in Eurasia and represented by two sub-clades (1 and 2). The second clade was $B$. deitersi distributed in the Americas, it is represented by two sub-clades: 1 in South America $(B$. deitersi s.str.) and 2 in North America. Both geographic subclades had modest support. Further study is necessary to examine the independent status of North American populations. A third clade (Bosminopsis sp.) was detected from a single population in Thailand.

The tree based on the nuclear dataset $(18 S+28 S)$ had a similar topology to the mtDNA tree, but note that nuclear gene sequences were unavailable for Bosminopsis sp. from Thailand. The large clade of B. zernowi was again subdivided into two subclades (1 and 2) with low support. There were some conflicts between mitochondrial and nuclear sequences. Some specimens from the mitochondrial sub-clade 1 belonged to the nuclear sub-clade 2 (they are marked by asterisks in Supplementary Figure S1, A-B). As support for both mitochondrial and nuclear subclades was low, we do not discuss this below. The $18 S$ locus was almost identical in all populations, suggesting the locus is most informative at the genus level. The $28 S$ locus 
322 demonstrated substantial variability in the D1 and D2 variable domains and appeared to contain

323 information for taxa within the genus. Based on the neutrality tests and coalescent simulations in

324 DnaSP v.6, we concluded that the most probable demographic model was a "bottleneck" model

325 reflecting historical processes.

326 The final tree based on combined mitochondrial and nuclear datasets (Supplementary

327 Figure S1C) was fully congruent with the mitochondrial tree - major clades were well-supported.

328 No conflicts were found for ML and BI (with unlinked data) trees among genes or with the 329 consensus tree.

330 The results of the phylogenetic reconstructions suggested a deep demographic subdivision

331

332

333

334

335

336

337

338

339

340

341

342

343

344

of the $B$. deitersi group. The tests of neutrality were consistent with such a division (Fu's $\mathrm{Fs}_{\mathbf{s}}<=0$ with Tajima $\mathrm{D}>>0$ ). The most probable demographic process in this group evolution was an expansion with a strong founder effect resulting in strong differentiation between populations.

We further explored the genetic diversity within each group and addressed the taxonomic uncertainty within these lineages.

For cybertaxonomic taxon delimitations (Fig. 2), both bGMYC and mPTP (for both mitochondrial and nuclear genes) suggested a deep divergence within the B. deitersi group. All approaches suggested an independent status of B. zernowi, B. deitersi and Bosminopsis sp. from Thailand. Only the nuclear tree suggested a "Far Eastern" sub-clade based on the information in the hypervariable domains D1 and D2. There was some evidence that North American and South American populations of $B$. deitersi form independent species. More sampling of North American populations and loci is warranted to test this hypothesis further. Compared to bGMYC and mPTP, STACEY suggested significantly more taxa. However, increased splitting is expected (compared to morphological evidence) with STACEY (Jones, 2017; Vitecek et al., 2017). 
To estimate divergences among selected OTUs, we calculated "simple" uncorrected $p$ -

346 distances for the best sampled locus, $16 S$ (Table 2). Bosmina was the outgroup. Distances among

347 outgroups are ca. two times greater than the maximum distances within the $B$. deitersi groups.

348 Groups "Eurasia", "Thailand", and "Americas" are well-differentiated, while differences between

349 two sub-clades of Eurasia are less than $0.5 \%$. The two subclades may result from moderately

350 separated mitochondrial lineages, which are common in cladocerans (Bekker et al., 2018; Kotov

351 et al., 2021). Again, North and South American populations may be separate species, but more

352 sequences are needed to test this hypothesis.

353 A network of $16 S$ mitochondrial haplotypes (Fig. 3) revealed that all populations from

354 Northern Eurasia belonged to only four haplotypes (Fig. 2): haplotype H1 included 73\% of

355 studied specimens and distributed from the Volga basin in European Russia to Pacific coast

356 including Sakhalin Island (but not in Korea and Japan). H2 haplotype was endemic to the

357 Yenisey Basin in Eastern Siberia and seemed to be a derivate of H1. Another well-represented

358 haplotype (H3) differed by two substitutions from H1and was associated with a rare haplotype

359 H4. H3 and H4 were detected only in Japan and Korea. Overall, haplotypic differentiation within 360 groups was weak.

361 The Maximum Likelihood tests (Table 3) suggested that the hypothesis of molecular

362 clocks is not rejected for each locus tested. In general, the topology of the tree constructed for the 363 molecular clock calculations (Fig. 4A) is congruent with the multilocus tree described above.

364 Differences in the divergence pattern of the American (B. deitersi) and Thailand (B. sp.) clades

365 may be explained by heterochrony in the appearance and fixation of the substitutions in

366 mitochondrial and nuclear genomes (Vawter \& Brown, 1986). Minor heterochrony is not an

367 insurmountable obstacle for phylogenetic reconstructions (Allio et al., 2017). 
"Simple" p-distances between B. zernowi and B. deitersi (based on the COI locus), gave a

369

370

371

372

373

374

375

divergence time estimate of 17-30 MYA $(p=0.241)$. The estimate used an average divergence time for crustaceans of ca. $0.8-1.4 \%$ per $1 \mathrm{Myr}$, which is similar to the age of divergence based on the coalescent model (Fig. 4A). Based on the time of divergence of the outgroup (Bosmina), we estimated the divergence of the $B$. deitersi group at around 200 MYA. Using RASP4, the taxa under consideration had an origin consistent with Laurasia (ancestral distribution range (C(ABCGEF)G), see Fig. 4B, 4C). However, note that Gondwanan populations from Africa, Australia, and India were not studied here. An alternative explanation is that the divergence of Bosminopsis sp. could be explained by its Gondwanan proto-range and subsequent colonization of Eurasia (i.e., due to India's continental drift). Bosminopsis sp. (ancestral range (G)) was separated in the Early Cretaceous from a Euro-Asian-American population of the group $(\mathrm{CE}(\mathrm{AB}) \mathrm{GF}))$. Subsequent history was probably related to the disruption of Laurasia into Eurasian $(\mathrm{CA}(\mathrm{BCG}))$ and American $(\mathrm{EF})$ groups of populations also in Cretaceous. Separation of North (F) and South American (E) populations had no ready explanation - it may be associated with the Gondwana-Laurasia split in the Cretaceous or a significantly more recent dispersal event (Neogene). A strong founder effect could then explain the genetic differences between Neogene populations of the two continents. In any event, the divergence of the entire Bosminopsis group is likely very ancient (at least the Early Cretaceous) and potentially affected by the split of proto-continents.

\author{
Morphological analysis
}

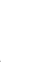

(1)

Order Anomopoda Sars, 1865 
391

392

394

395

396

397

398

399

400

401

402

403

404

405

406

407

408

409

410

411

412

413

\section{Family Bosminidae Baird, 1845}

\section{Genus Bosminopsis Richard, 1895}

Short diagnosis. Dorsal head pores absent in adults. Basal spine on postabdominal claw

very large, as large as claw itself. Antennae I in females with proximal parts fused. Both exopod and endopod of antenna II three-segmented, antennal formula 0-0-3/1-1-3. Five pairs of thoracic limbs.

\section{Checklist of the formal taxa in the genus Bosminopsis}

1. Bosminopsis deitersi Richard, 1895 - valid species.

2. Bosminopsis zernowi Linko, 1901 - valid species.

3. Bosminella Anisitsi Daday, 1903 - junior synonym of B. deitersi.

4. Bosminopsis ishikawai Klocke, 1903 - junior synonym of B. zernowi.

5. Bosminella Anisitsi var. africana Daday, 1908 - status must be checked, it could be a valid species.

6. Bosminopsis deitersi var. typica Burckhardt, 1909 - junior synonym of B. deitersi.

7. Bosminopsis deitersi birgei Burckhardt, 1924 - valid species.

8. Bosminopsis deitersi brehmi Burckhardt, 1924 - junior synonym of B. africana.

9. Bosminopsis deitersi klockei Burckhardt, 1909 - junior synonym of B. zernowi.

10. Bosminopsis deirestsi pernodi Burckhardt, 1924 - possible junior synonym of B.

zernowi.

11. Bosminopsis deirestsi schroeteri Burckhardt, 1924 - junior synonym of B. zernowi.

12. Bosminopsis stingelini Burckhardt, 1924 - junior synonym of B. deitersi.

13. Bosminopsis deitersi var. africana Rahm, 1956 - junior homonym of B. africana. 

from SE Asia.

History Museum, Budapest, Hungary.

\section{Bosminopsis deitersi group}

Diagnosis. Valve with a single mucro or several mucro-like spines at postero-ventral valve portion. No postero-dorsal spine (caudal needle) on carapace. Basis of postabdominal setae not 429 inflated.

two valid species are not members of the $B$. deitersi group, both are andemics of Amazonia (B. negrensis and $B$. brandorffi, numbers 14 and 17 in our checklist). Most taxa of the $B$. deitersi group were poorly described. Here we try to start the revision of the group, redescribing $B$. 
437

438

439

440

441

442

443

444

445

446

447

448

449

450

451

452

453

454

455

456

457

458

459

\section{Bosminopsis deitersi Richard, 1895 s.str.}

Figures 5A-E, 6-9

Bosminopsis deitersi Richard 1895. Richard, 1895, p. 96-98, figs 1-4; Richard, 1897, p.

283-286, figs 28-31; Stingelin, 1904, p. 584-586, Pl. 20: figs 7-10; Burckhardt, 1909, p. 251;

Burckhardt, 1924, p. 221-228; Rey \& Vasquez, 1986, p. 222-225, P1. 2: figs 1-16; Kotov, 1997a,

p. 26-29, figs 1-2; Kotov, 1997b, p. 6-26, figs 1-13; Kotov \& Ferrari, 2010, p. 51.

Bosminopsis deitersi var. typica n.n. in Burckhardt, 1909, p. 251.

Bosminopsis stingelini Burckhardt 1909. Burckhardt, 1909, p. 251, text-figure: A-B;

Burckhardt, 1924, p. 228-229, figs 2, 8.

Bosminopsis macaguensis Rey and Vásquez 1986. Rey \& Vasquez, 1986, p. 220-222, Pl.

1: figs $1-18$.

Bosminella Anisitsi Daday 1903. Daday, 1903, p. 594-597, figs 1-3; Daday, 1905, p. 199200, P1. 13: figs $1-5$.

Type locality. "... l'eau douce à La Plata (Buenos-Ayres)" (Richard, 1895), Argentina.

Type material. Lost, absent in the Collection of Jules Richard at the National Museum of Natural History, U.S.A. (Kotov \& Ferrari, 2010).

Material studied here. See Supplementary Table S1.

Short diagnosis. Body of large adult parhenogenetic female subovoid, in younger adults more elongated, with a short postero-dorsal spine, but a caudal needle absent. Reticulation wellexpressed on valves and head. Valve with a single short mucro at postero-ventral valve portion, or it is completely reduced. Postabdomen without inflated basis of postabdominal setae. Limb I 
460 with epipopite having two finger-like projections. Juvenile female with a long postero-ventral

461 mucro, supplied by minute denticles. Free and fused parts of antennae I, mucro, rostrum, ventral

462 valve edge, base of caudal spine covered with small spinules. Ephippial female with egg

463 chamber sculpture represented by large polygons. A strong medial keel on dorsum, strong paired

464 lateral keels well distinguishable from the dorsal view. Adult male with dorsal contour of head

465 humped, head large, with a smooth rostrum and expressed ocular dome, a short mucro always

466 present postero-ventrally. Postabdominal claw bears a basal spine comparable in size with the

467 latter. Antenna I free, remarkably curved distally. A relatively long (somewhat longer than

468 exopod itself), curved at tip additional male seta on endopod apical segment in position of a

469 rudimentary spine in female. Limb I a copulatory hook relatively large and regularly thick, its tip

470 blunt. Size $0.17-0.41$.

471

472

473

474

475

476

477

478

479

480

481

482

\section{Redescription}

Adult parthenogenetic female. Body short and almost round in lateral view (body

height/length ratio about $0.65-0.69$ ), dorsal margin regularly curved from base of antenna I to posterodorsal angle (Figs 5A, 6A). Reticulation prominent, both on head and on valves. Posterior margin straight, with height about half of total body height, postero-dorsal angle expressed. Head in lateral view with a low ocular dome (Fig. 6B), body contour between head and proboscis rostral part (fused bases of antennae I) depressed. Frontal head pore ovoid, located almost in the middle of rostral part, somewhat anteriorly to level of frontal sensory setae (Fig. 6C-D). Lateral and dorsal head pores absent in adults. Compound eye of moderate size. Ocellus absent. Labrum as a fleshy appendage, its anterior contour convex. Antero-ventral portion of valves with setulated setae (Fig. 6E), ventral margin slightly convex, with a series of spinules, a long seta 
483 (seta Kurzi) and a rudimentary mucro at poster-ventral angle (Fig. 6F-G). Postabdomen

484 compressed laterally, slightly and regularly narrowing distally, without inflated basis of

485 postabdominal setae (Fig. 7A-C). Preanal margin long, straight to slightly concave, without

486 setules. Anal margin straight, preanal angle expressed, but postanal angle absent. Anal and

487 postanal portion with small denticles and as a postabdominal claw terminally supplied with a

488 strong basal spine, almost as large as claw, both claw and basal spine slightly curved.

489 Postabdominal seta bisegmented, shorter than postabdomen.

490 Proximal portions of two antennae I fused together and with rostrum, both lateral portions

491 directed downwards and slightly curved laterally (Fig. 6C-D, H). Antennular sensory setae

492 located on fused portion of antennas I. Distal portions with nine aesthetascs subequal in size.

493 Antenna II (Fig. 6I) with a coxal portion bearing a long seta and a short seta on a conical

494 elevation, elongated basal segment and short three-segmented exopod and endopod, antennal

495 formula: setae $0-0-3 / 1-1-3$; spines $0-0-1 / 0-0-1$, but apical spines greatly reduced in size. All

496 apical and lateral (on endopod first and second segment) setae subequal in size, covered by fine

497 setules.

498 Limb I large, its corm conically narrowing distally. Epipodite (Fig. 7D: epp) with two long

499 finger-like projections. Outer distal lobe (Fig. 7D: odl) with two setae of different size, feathered

500 by sparse, long, robust setules. Inner subdistal lobe (in terms of Kotov 1997a) (Fig. 7D: isl) with

501 a single seta, densely fringed by delicate setules. On inner limb edge, three soft setae. A bunch of

502 long setules is located near these setae. Two robust ejector hooks (Fig. 7D: ejh) strongly different

503 in size, armed with short denticles. The maxillar process (Fig. 7D: mxp), a derivative of

504 gnathobase I, with a single long, densely setulated seta, at base of the limb.

505 Limb II relatively small, with epipodite supplied by a finger-like projection. Inner limb 
506 portion with an anterior row of 6 setae (homologs of "scrapers" of the chydorids, see Fryer,

507 1968) (Fig. 7E: 1-6) and disjuncted posterior row two setae (Fig. 7E: pos): a seta near

508 gnathobase and another one near the proximal end of the limb. Gnathobase II with distal

509 armature (Fig. 7E: dag) of three setae of different armature. Filter plate consists of five long

510 setulated setae (Fig. 7E: fpl).

511 Limb III with epipodite (Fig. 7F: epp) supplied with a finger-like projection. Exopodite

512 rectangular, bearing two lateral (Fig. 7F: lat=6-7) and five (Fig. 7F: dis $=1-5$ ) distal setae, seta 1

513 shorthest among distal setae. Each seta covered by long setules. Distal endite (in terms of Kotov

514 2013) with three anterior setae (Fig. 7F, G: 1-3): setae 1 and 2 long; seta 3 especially short.

515 Proximal endite with two small anterior setae (Fig. 7F, G: 4-5). Eight soft setae on posterior face

516 of limb, plus a seta of unclear homology (Fig. 7F: ?). Distal armature of gnathobase (Fig. 7F:

517 dag) with three setae and a small sensillum. Filter plate (Fig. 7F: fpl) with five setae of subequal

518 size.

519 Limb IV with small ovoid setulated pre-epipodite (Fig. 7H: pep) and a finger-like epipodite

520 (Fig. 7H: epp). Exopodite circular with eight soft setae (1-8), no subdivision into lateral and

521 distal setae. The longest seta covered by fine stiff setulae, others with long setules. The

522 distalmost portion of exopodite as a densely setulated flat lobe. Inner distal portion with four

523 anterior setae (Fig. 7H: 1-4); among them distal most setae 1 especially thick. Four thin long

524 setae on posterior limb face. Distal armature of gnathobase (Fig. 7H: dag) with two elements

525 represented by a thin sensillae. Filter plate (Fig. 7H: fpl) with four setae subequal in size.

526 Limb V (Fig. 7I) with a small, ovoid setulated preepipodite and an epipodite supplied with

527 a long finger-like projection. Exopodite with five soft setae (1-5) covered by long setules, seta 5

528 exceptionally long. The distalmost portion of limb as a densely setulated flat lobe, two soft setae 
529

530

531

532

533

534

535

536

537

538

539

540

541

542

543

544

545

546

547

548

549

550

551

near it, two setulated setae of subequal length near gnathobase. Filter plate with two long setae.

Juvenile female. Instar I has a dorsal head pore (Kotov, 1997b). Body elongated, head

relatively high, elevating over valves, without a cervical incision (Fig. 5E). Carapace with a short

posterior spine and a long postero-ventral mucro, supplied with minute denticles. Antenna I

relatively longer than in female. Free and fused parts of antennules, mucro, rostrum, ventral

valve edge, base of caudal spine covered with relatively small spinules.

Ephippial female. Only dorsal portion of valves modified as compared to parthenogenetic

female (Fig. 5B-D, 6J-K). Ephippium yellowish, ovoid, not clearly demarked from ventral and

lateral portions of valves. Egg chamber with a single egg, elongated, its sculpture represented by

large polygons well visible under light microscope with very clearly, minute wrinkles and

tubercles in each polygon. A strong medial keel on dorsum, strong paired lateral keels well

distinguishable from the dorsal view. From the dorsal view, keels projected laterally out of body

contour.

Juvenile male. Body elongated, with a clear dorsal depression posteriorly to head (Fig.

8A-B). Head large, with ill-developed ocular dome (Fig. 8C-D). Armature of antero-ventral

valve portion (Fig. 8E) as in female. Mucro well-developed (Fig. 8G-H). Postabdomen short, gonopores not visible (Fig. 8I-J). Antennae I fused to rostrum, but their bases are not fused together (Fig. 9D). Limb I with a short, thick copulatory hook (Fig. 8K-M).

Adult male. Shape significantly different from that in female, body short (body

height/length ratio about 0.65 ), dorsal contour of head humped, dorsal contour of carapace straight, valve anterior portion with few setae anteriorly, ventral margin convex, with setules as in female (Fig. 9A). Head large, with a smooth rostrum and expressed ocular dome, compound eye large (Fig. 9B-C). Valve armature as in female (Fig. 9D), but a short mucro always present 
552 postero-ventrally (Fig. 9E). Postabdomen similar with that in female, its ventral margin slightly

553 comvex, preanal margin slightly to moderately concave. Anal margin almost straight, postanal

554 angle absent. Postabdominal claw bears a basal spine comparable in size with the latter (Fig. 9F),

555 both claw and basal spine slightly and regularly bent.

556 Antenna I free, remarkably curved distally (Fig. 9G). Frontal sensory seta long, located at

557 middle of antennular body, a short male seta somewhat anteriorly to that, several fields of short

558 spinules located at antenna I anterior face. Long aesthetascs located subterminally, two of them

559 are located on the tip of antenna I, the others located on its lateral surface in two rows. Antenna

560 II with apical and lateral setae as in female. A relatively long (somewhat longer than exopod

561 itself), curved at tip additional male seta on endopod apical segment in position of a rudimentary

562 spine in female (Fig. 9H). Limb I with outer distal lobe bearing two setae strongly unequal in

563 size, copulatory hook relatively large and regularly thick, its tip blunt, not expanded bearing

564 small denticles (Fig. 9I).

565 Size. Females $0.17-0.45 \mathrm{~mm}$, adult males $0.29-0.31 \mathrm{~mm}$.

566 Differential diagnosis. $B$. deitersi differs from $B$. zernowi in (1) only a single mucro at

567 postero-ventral valve angle in both females and males; (2) different proportions of setae in

568 exopodite, inner limb portion and distal armature of gnathobase of limb III and on exopodite V;

569 (3) male basal spine on postabdominal claw significantly shorter that the claw itself; (4) male

570 antenna I strongly bent distally; and (5) additional seta on apical segment of male antenna II

571 curved at tip. Morphological differences from other taxa revealed above genetically are not

572 studied yet.

573 Distribution and ecology. Widely distributed in the Neotropical zone. Records from

574 Mexico (Elias-Gutierrez et al., 2008) and Central America (Collado, Fernando \& Sephton, 
575 1984) need to be checked as they could belong to $B$. deitersi s.str. or the poorly described $B$.

576 birgei.

577 Populations with a single mucro in juveniles are present on other continents (Fig. 5F-H),

578 but they belong to other taxa that need to be revised.

579

580

\section{Bosminopsis zernowi Linko, 1901}

581

Figures 10-14

582

583

gen.? sp.? in Zernov, 1901, p. 34, P1. 4: Fig. 27.

584

Bosminopsis zernowi Linko 1901. Linko, 1901, p. 345-347, text-fig.; Meissner, 1902, p.

585

52; Meissner, 1903, p. 180-190, Plates 2-4; Zykoff, 1906, p. 22-24, text-fig.; Burckhardt, 1909,

586

p. 251; Burckhardt, 1924, p. 229-230.

587

Bosminopsis deitersi zernowi in Behning, 1941, p. 190-191, Fig. 83; Manujlova, 1964, p.

588

265, Fig. $147(1,3)$.

589

Bosminopsis deitersi in Krasnodebski, 1937, p. 357-360, P1. 12: Fig. 1; Smirnov et al.,

590

1995, p. 66, Fig. 58 (1-2); Song \& Mizuno, 1982, p. 343, Fig. 2-3; Yoon \& Kim, 1987, p. 194,

591 Fig. 8e-g; Kim, 1988, p. 58, Fig. 40; Lieder, 1996, p. 29-31, Fig. 1a-c, 2a-f; Tanaka, 2000, p.

592 110, Fig.1-2; Yoon, 2010, p. 94-95, Fig. 49; Jeong, Kotov \& Lee, 2014, p. 221; Bledzki \&

593 Rybak, 2016, p. 172.

594 Bosminopsis ishikawai Klocke 1903. Klocke, 1903, p. 130-134, figs 5-8, Pl. 4: figs 2, 6;

595 Burckhardt, 1924, p. 222.

596 Bosminopsis klockei Burckhardt 1909. Burckhardt, 1909, p. 251; Burckhardt, 1924, p. 222.

597 Bosminopsis pernodi Burckhardt 1909. Burckhardt, 1909, p. 251; Burckhardt, 1924, p. 
598

599

600

601

602

603

604

605

606

607

608

609

610

611

612

613

614

615

616

617

618

619

620

222.

Bosminopsis deitersi pernodi in Manujlova 1964, p. 265.

Bosminopsis schroeteri Burckhardt 1909. Burckhardt, 1909, p. 251; Burckhardt, 1924, p.

229, Fig. 1, 4, 6-7.

Type locality. "Flusse Wjatka gefunden" = the Vyatka River (affluent of the Kama River which is a large affluent of Volga) near Malmyzh (Zernov, 1901), Kirov Area, European Russia.

\section{Type material. Lost.}

Material studied here. See Supplementary Table S1.

Short diagnosis. Body of large adult parhenogenetic female (Figs 10A, 11A-B) subovoid, in younger adults more elongated, with a short postero-dorsal spine, but a caudal needle absent. Reticulation ill-expressed on valves and head (Fig. 11C-D). Valve (Fig. 11E-H) with a series of mucro-like spines at postero-ventral valve portion, or they are completely reduced. Postabdomen without inflated basis of postabdominal setae (Fig. 12A-C). Antenna I and II (Fig. 11I-J) as in previous species. Limb I with epipopide having two finger-like projections, limbs in general as in previous species (Fig. 12D-M), but seta 1 en exopodite III relatively shorter, seta 7 there relatively longer (Fig. 12F), seta 2 on inner-distal limb portion longer than seta 1, longest setae in distal armature of gnathobase III strongly longer than other setae (Fig. 12G); on exopodite V, seta 2 and 3 short (Fig. 12M). Juvenile female (Fig. 10F-G) with a series of long, thin mucrolike spines. Free and fused parts of antennae I, mucro, rostrum, ventral valve edge, base of caudal spine covered with small spinules. Ephippial female (Figs 10B-D, 11K-L) with egg chamber sculpture represented by large polygons, but this sculpture is less represented as compare too previous species. A strong medial keel on dorsum, strong paired lateral keels well 
621 distinguishable from the dorsal view. Juvenile male (Fig. 10H, Fig. 13) as in previous species.

622 Adult male with a dorsal contour of head humped (Fig. 14A); head large (Fig 14B-C), with a

623 smooth rostrum and expressed ocular dome, a series of mucro-like spines always present

624 postero-ventrally. Valve as in female (Fig. 14D-E). Basal spine on postabdominal claw shorter

625 than the claw itself (Fig. 14F). Antenna I free, its distal portion only slightly bent (Fig. 14C, G).

626 A long additional male seta on endopod not curved at tip (Fig. 14H). Limb I with a copulatory

627 hook (Fig. 14I) relatively more massive that in previous species.

628 Size. Females $0.25-0.47 \mathrm{~mm}$, adult males $0.26-0.30 \mathrm{~mm}$.

629 Differential diagnosis. It differs from $B$. deitersi in (1) several mucro-like spines at

630 postero-ventral valve angle in both females and males; (2) different proportions of setae in

631 exopodite, inner limb portion and distal armature of gnathobase of limb III and on exopodite V;

632 (3) male basal spine on postabdominal claw approximately as long as claw itself; (4) male

633 antenna I almost not bent distally; (5) additional seta on apical segment of male antenna II

634 without curved tip.

635 Distribution. In Europe, B. zernowi is recorded from the Neman basin in Poland (Wolski, 636 1932), Dniepr River basin (including Dniepr itself, Desna and Pripyat, in Ukraine and Belarus, 637 and, most probably, the Russian portion of the basin) (Werestchagin, 1912; Charleman, 1915, 638 1922; Vezhnovets, 2005). Bledzki and Rybak (Bledzki \& Rybak, 2016) included the Danube 639 basin as the part of its range, but no records from this river are known to us. Negrea (Negrea, 640 1983) wrote that the species "could be present in Romania", but to date it was not recorded from 641 this country. In European Russia, B. zernowi was recorded from many rivers of the Volga basin, 642 including the Volga itself, Kostroma, Wyatka, Kama, Kerzhenets, Sura, Kubra, Oka, Nara, and 643 Moskva rivers (Skadowskiy; Meissner, 1902; Skorikov, Bolokhontsev \& Meissner, 1903; Zykoff, 
644 1906; Greze, 1921; Muraveisky, 1924; Behning, 1928; Greze, 1929; Rylov, 1940; Tarbeev et al.,

645 2011). The species was found in the basins of all the great rivers of Western and Eastern Siberia:

646 the Ob' River basin (Leschinskaya, 1962) including its Arctic portion (Werestchagin, 1913), the

647 Tom' River (Petlina et al., 2000) and the Chulym River (Kukharskaya \& Dolgin, 2009);

648 Subarctic portion of the Yenisey River (Pirozhnikov, 1937); Lena River (Abramova \& Zhulai,

649 2016), Amur River basin (Afonina, 2013). The opinion of Manujlova (Manujlova) that "in the

650 USSR it was not found east to Ob' River" was based on inadequate knowledge of previous

651 literature, i.e. (Pirozhnikov, 1937). It is widely distributed in Korea (Cho \& Mizuno, 1977) (also

652 see descriptions above) and Japan (Ueno, 1937b) (and our data), and present in South China and

653 Vietnam (our data). Most probably, it is present on the Pacific coast of Asia from the Amur to

654 the Mekong basins.

655 But previous records from China (Ueno, 1932; Ueno, 1944; Mashiko, 1953; Du Nan-shan,

656 1973; Chiang \& Du, 1979; Xiang et al., 2015) need to be checked, as they could belong both to

657 B. zernowi (Amur basin) (i.e. (Ueno, 1937a; Ueno, 1940)) and the SE Asia taxon (at least some

658 populations in southernmost China). "B. schröteri" described from "Sutschaufluss bei

659 Schanghai" (Burckhardt, 1909), is a junior synonym of B. zernowi (as it has several mucro-like

660 spines at postero-ventral angle).

661 Most probably, the tropical countries of Asia are fully populated by other taxa, as in all

662 illustrations the females have a single strong mucro (Rane, 1984; Idris, 1983; Michael \&

663 Sharma, 1988; Pascual et al., 2014). Also, a single mucro is illustrated in the figures of

664 Bosminopsis from North America (Birge, 1918), Africa (Korinek, 1984) and Australia (Smirnov

$665 \&$ Timms, 1983) (Fig. 15).

666

Peer] reviewing PDF | (2021:01:57215:2:0:NEW 21 Mar 2021) 


\section{Discussion}

668

669

670

671

672

673

674

675

676

677

678

679

680

681

682

683

684

685

686

687

688

\section{Old Mesozoic group}

Our results are consistent with the hypothesis that $B$. deitersi is, in fact, a species group.

We find no evidence for the nominate species in the Palearctic. However, we did find evidence for a genetically divergent and morphologically differentiated Old World lineage. Notably, the strong genetic divergences that we observed and our ancient age estimates were unaccompanied by strong morphological divergences. With our integrated approach, we hoped to mitigate some of the limitations of molecular datasets. As coalescent analyses can oversplit taxa, multigene data benefit from morphological and ecological information. Single gene datasets may disagree with one another and with the species tree for manifold reasons (Fisher-Reid \& Wiens, 2011; Hailer et al., 2012). In the present analysis, the topological disagreements (e.g. subclades) were weakly supported, indicating that random error may play a role.

A mature biogeography is only possible with an understanding of timescale (Rosen, 1978). The antiquity of cladocerans of different ranks, from genera to orders, has been confirmed by the fossil record, i.e., from the Mesozoic (Smirnov, 1992; Kotov \& Korovchinsky, 2006; Kotov \& Taylor, 2011; Liao et al., 2020). Unfortunately, the Palaeozoic records (Anderson, Crighton \& Hass, 2004; Womack et al., 2012) are dubious: the described animals could belong to the Cladocera, but also could be members of other crustacean groups (Van Damme \& Kotov, 2016). Kotov and Taylor (Kotov \& Taylor, 2011) demonstrated that extant genera of the Daphniidae and even the subgenera of the genus Daphnia existed at the Jurassic/Cretaceous boundary, ca. 145 MYA. More fossil calibrations are possible for the group. 
690 (Sacherova \& Hebert, 2003; Schwentner et al., 2013; Cornetti et al., 2019). Perhaps the only

691 known calibration point for relaxed molecular clocks is the

692 Daphnia/Ctenodaphnia/Simocephalus split at 145 MYA (Kotov \& Taylor, 2011). Non-calibrated

693 molecular clocks also suggest earlier differentiation of the cladocerans, i.e., differentiation of the

694 subfamilies within Chydoridae in the mid-Palaeozoic (Sacherova \& Hebert, 2003). A fast

695 molecular clock estimate gave a divergence time for Daphnia at more than 66 MYA (Cornetti et

696 al., 2019). This value is probably too young given the calibration point of 145 MYA. A more

697 realistic estimate should exceed the minimum fossil calibration (Kotov, 2013). very rough estimation (see Fig. 4A) suggests that the Bosminidae could be even older than the Daphniidae. Such a conclusion agrees with the hypothesis that bosminids are a sister group to Chydoridae (Kotov, 2013). Chydorids are probably of Palaeozoic origin (Sacherova \& Hebert, 2003). No Mesozoic bosminids are known to date. Bosmina was one of the first genera to be studied with paleolimnology. Unlike Bosmina, subfossil remains for Bosminopsis are unknown from the Holocene and Pleistocene bottom sediments (Austin, 1942; Hofmann, 1984). It seems unlikely that a detailed fossil record will be found for Bosminopsis. So molecular clocks are the only method to estimate the time of its differentiation. We estimate that the differentiation of the main Bosminopsis lineages took place in the Cretaceous, and coincided with the disruption of Pangaea, or later disruption of Laurasia. Mesozoic lineages survived in SE Asia and elsewhere in

Eurasia (the exact location is unclear) after a mass extinction during the mid-Caenozoic

711 ("Far East") was the center of B. zernowi diversificaton, as this region is the richest in 
712 mitochondrial haplotypes (Fig. 3), and is often a center of diversity for cladoceran taxa (Kotov et 713 al., 2021).

While there is strong genetic divergence between New World and Old World lineages, a

715

716

717

718

719

720

721

722

723

724

725

726

727

728

729

730

731

732

733

734 more detailed assessment of the divergence time awaits further geographic and genomic

sampling for the New World. Within B. zernowi, our results suggest a mitochondrial

mitochondrial haplotypes was weak.

Korovchinsky (Korovchinsky, 2006) postulated that extant cladocerans are relicts of a mass extinction in the mid-late Caenozoic. For Cladocera, Pleistocene mass extinction in the Holarctic due to glaciation and aridization (Hewitt, 2000) also has phylogeographic support (Taylor, Finston \& Hebert, 1998; Cox \& Hebert, 2001). But phylogeographic publications referring to previous epochs with non-Holarctic samples are rare (Xu et al., 2009; Kotov et al., 2021). For Bosminopsis, our results suggest a Mesozoic differentiation of the lineages and then survival of only two main lineages in the mid-Caenozoic. We failed to detect divergences consistent with the Quaternary. Our results are consistent with contintental endemism and longterm morphological stasis.

Morphological divergence in Bosminopsis appears to be weak since the Mesozoic. This divergence involves fine-scaled characters such as the mucro-like spine number, male basal spine, and antenna I appearance and armature. Such subtle differences among species are known in other cladoceran groups (Kotov et al., 2021) but can only rarely be associated with a timescale. There are no known fossil records for the globally distributed B. deitersi group. However, Bosminopsis may be a "living fossil" sensu Darwin (Darwin, 1859). The B. deitersi group has survived with very little morphological change since the Mesozoic despite profound abiotic and 
735 biotic changes to the continental water bodies over this timescale. Our results indicate that the

736 occupation of differing climates has also left a weak morphological signature. While the concept

737 of "living fossil" is somewhat ambiguous (Casane \& Laurenti, 2013) there are several groups

738 that appear to have undergone morphological stasis since the Mesozoic. Our evidence is

739 consistent with Frey (1962) who expected stasis to account for continental endemism in

740 Cladocerans.

741

742

Preliminary comments on further taxonomic revision

Further studies are needed to demonstrate that the North American populations form a

744

745

746

747

748

749

750

751

752

753

754

755

756

757 separate species from South American specimens. If so, then the taxonomic name for North American specimens would be Bosminopsis birgei Burckhardt, 1924. Records of Bosminopsis are infrequent in North America and are mainly from the southeastern USA (Pennak, 1953; Beaver et al., 2018). Recent biotic exchange between North America and South America has occurred for several cladoceran genera (Mergeay et al., 2008). In such cases, there is very little genetic differentiation for mitochondrial markers among continents. The status of populations from East Asia (Idris, 1983; Michael \& Sharma, 1988) must also be addressed, including that of B. devendrari Rane (a possible proper name for the SE taxon recorded above). To date, we have no information on Bosminopsis cf. deitersi from Africa, i.e., described by Daday (Daday, 1908) from Lake Nyassa as Bosminella Anisitsi var. africana with a single mucro. This taxon is found in different African countries (Brehm, 1913; Rahm, 1956; Korinek, 1984). The status of Australian populations (Smirnov \& Timms, 1983), also having single mucro, remains unclear. Subtle geographic variation in the morphology of Bosminopsis has been known since the early 1900’s. Meissner (Meissner, 1903) and Klocke (Klocke, 1903), for example, pointed out 
758 the numerous stout spines at the postero-ventral corner of the valves from Russian and Japanese

759 Bosminopsis - the most prominent difference between B. deitersi and B. zernowi. Still,

760 subsequent authors failed to recognize this variation as taxonomically valuable. Klocke (Klocke,

761 1903) concluded that there are two species in Japan, B. ishikawai and B. deitersi. He concluded

762 that the former has stronger denticles on antenna I, better-developed reticulation, a postero-dorsal

763 projection located more dorsally and longer spines at postero-dorsal angle "making it similar to

764 Ilyocryptus". In reality, all listed differences are characteristic of juvenile females. Therefore,

765 Klocke (Klocke, 1903) erroneously regarded the populations with large adults and without large

766 adults those as two separate species. The same mistake was made by Rey and Vasquez (Rey \&

767 Vasquez, 1986), who described B. macaguensis referring to differences of juvenile males of $B$.

768 deitersi in Venezuelan populations (Kotov, 1997a).

769

770

\section{Conclusions}

771

772

Here we revised only populations from Eurasia. Other taxa discussed above in the genetic

773

section must be reconsidered in the future, and biological differences must be studied in detail.

774 Each of these putative species has a single mucro at a postero-dorsal angle and minimal differences between parthenogenetic females. We expect that comparing males will be the most

776 fruitful for assessing morphological diagnoses, as male morphology tends to differ among

777 species more than female morphology in cladocerans (Popova et al., 2016; Sinev, Karabanov \& 778 Kotov, 2020).

779 
All data generated or analysed during this study are included in Open Science Framework

782

783

784

785

786

787

788

789

790

791

792

793

794

795

796

797

798

799

800

801

802

803

804

project (https://osf.io/4fjnm/) and this published article. All sequences are deposited at the NCBI

GenBank accs. no. MT757174-MT757274, MT757314-MT757388, MT757459-MT757473.

Specimen series from which DNA was extracted are deposited at Zoological Museum of

Moscow State University.

\section{Acknowledgements}

Many thanks to E.S. Chertoprud, D.E. Gavrilko, L. Hovind, S. Ishida, H.G. Jeong, N.M. Korovchinsky, W.H. Piel, D.E. Shcherbakov, A.Y. Sinev for zooplankton samples, K.S. Chae, H.J. Dumont, B.P. Han, S.J. Ji, H.S. Kim for assistance during sampling. SEM works are carried out at the Joint Usage Center "Instrumental Methods in Ecology" at A.N. Severtsov Institute of Ecology and Evolution of Russian Academy of Sciences.

\section{Funding}

Whole this study was supported exclusively by the Russian Science Foundation (grant no. 18-14-00325 for PGG. DPK, ANN and AAK) except of sample collecting preceding the project. Sampling in South Korea was supported by a grant from of the National Institute of Biological Resources (NIBR), funded by the Ministry of Environment (MOE) of the Republic of Korea for AK. DJT has no specific support.

\section{Authors' contributions}

PeerJ reviewing PDF | (2021:01:57215:2:0:NEW 21 Mar 2021) 
806

807

808

809

810

811

812

813

814

815

816

817

818

819

820

821

822

823

824

825

826

827

828

829

830

831

832

833

834

835

836

837

838

839

and subsequent analysis of phylogenetic information, all authors participated in the writing of different portions of the manuscript.

\section{References}

Abramova EN, Zhulai IA. 2016. Appearance of new zooplankton species in water bodies of the Lena River delta. Trudy Zoologicheskogo Instituta Rossiyskoy Akademii Nauk 320 (4):473487.

Afonina EY. 2013. Review of rotifers (Rotifera) and crustaceans (Cladocera, Calanoida, Cyclopoida, Harpacticoida) diversity in streams and lakes of the Upper Amur River Basin. Amurian zoological journal 5 (3):248-255.

Allio R, Donega S, Galtier N, Nabholz B. 2017. Large variation in the ratio of mitochondrial to nuclear mutation rate across animals: implications for genetic diversity and the use of mitochondrial DNA as a molecular marker. Molecular biology and evolution 34 (11):27622772.

Anderson LI, Crighton WRB, Hass H. 2004. A new univalve crustacean from the Early Devonian Rhynie chert hot-spring complex. Transactions of the Royal Society of Edinburgh: Earth Sciences 94 (4):355-369.

Austin TS. 1942. The fossil species of Bosmina, App. 1 of Studies on Connecticut Lake sediments. American journal of science 240 (5):325-331.

Barido-Sottani J, Boskova V, Du Plessis L, Kuhnert D, Magnus C, Mitov V, Muller NF, PecErska J, Rasmussen DA, Zhang C, Drummond AJ, Heath TA, Pybus OG, Vaughan TG, Stadler T. 2018. Taming the BEAST - a community teaching material resource for BEAST2. Systematic biology 67 (1):170-174.

Beaver JR, Renicker TR, Tausz CE, Vitanye BT. 2018. Distribution of six taxa in the family Bosminidae Baird (Crustacea: Branchiopoda: Anomopoda) in the plankton of lakes and reservoirs within the continental United States, including expanded range of the invasive cladoceran Bosmina (Eubosmina) coregoni Baird. Zootaxa 4407 (4):506-520.

Behning AL. 1928. Materials on the hydrofauna of the assessory sysmems of the Volga River. V. Material on the hydrofauna of the Kama. Trudy Volzhskoy Biologicjeskoy Stantsii 9 (45):179-297.

Behning AL. 1941. Kladotsera Kavkaza - The Cladocerans of the Caucasus. Tbilisi: Gruzmedgiz Publishing. 
840

841

842

843

844

845

846

847

848

849

850

851

852

853

854

855

856

857

858

859

860

861

862

863

864

865

866

867

868

869

870

871

872

873

874

875

876

877

878

879

Bekker EI, Karabanov DP, Galimov YR, Haag CR, Neretina TV, Kotov AA. 2018. Phylogeography of Daphnia magna Straus (Crustacea: Cladocera) in Northern Eurasia: Evidence for a deep longitudinal split between mitochondrial lineages. PLoS one 13 (3): 0194045.

Birge EA. 1918. The water fleas (Cladocera). In: Ward HB, Whipple GC, eds. Freshwater biology. New York: John Wiley \& Sons, 676-740.

Bledzki LA, Rybak JI. 2016. Freshwater Crustacean Zooplankton of Europe. Cham: Springer International Publishing.

Boratyn GM, Camacho C, Cooper PS, Coulouris G, Fong A, Ma N, Madden TL, Matten WT, McGinnis SD, Merezhuk Y, Raytselis Y, Sayers EW, Tao T, Ye J, Zaretskaya I. 2013. BLAST: a more efficient report with usability improvements. Nucleic acids research 41 (Web Server issue):W29-33.

Bouckaert R, Vaughan TG, Barido-Sottani J, Duchene S, Fourment M, Gavryushkina A, Heled J, Jones G, Kuhnert D, Maio N de, Matschiner M, Mendes FK, Muller NF, Ogilvie HA, Du Plessis L, Popinga A, Rambaut A, Rasmussen D, Siveroni I, Suchard MA, Wu C-H, Xie D, Zhang C, Stadler T, Drummond AJ. 2019. BEAST 2.5 : An advanced software platform for Bayesian evolutionary analysis. PLoS computational biology 15 (4):e1006650.

Brandorff G-O. 1976. A new species of Bosminopsis (Crustacea, Cladocera) from the Rio Negro. Acta Amazonica 6 (1):109-114.

Brehm V. 1913. Cladoceren. Wissenschaftliche ergebnisse der zweiten deutschen Zentral Africa-Expedition 1910-1911 unter Fuhrung Adolf Friedrichs. Leipzig: Klinkhardt \& Biermann.

Brehm V. 1939. La fauna microscópica del lago Peten, Guatemala. Anales de la escuela nacional de ciencias biologicas 1 (2):173-203.

Burckhardt G. 1909. Neues uber das Bosminopsis Richard = Bosminella Daday. Zoologischer Anzeiger 34:248-253.

Burckhardt G. 1924. Wissenschaftliche Ergebnisse einer Reise um die Erde von M. Pernod und C. Schroter. III. Zooplankton aus ost- und sud-asiatischen Binnengewassern. Zeitschrift fur Hydrologie 2:217-242.

Carstens BC, Pelletier TA, Reid NM, Satler JD. 2013. How to fail at species delimitation. Molecular ecology 22 (17):4369-4383.

Casane D, Laurenti P. 2013. Why coelacanths are not 'living fossils': a review of molecular and morphological data. BioEssays 35 (4):332-338.

Charleman NW. 1915. On some crustaceans of the Dniepr. Entomologicheskiy Vestnik 2:125129.

Charleman NW. 1922. Bemerkung uber einige Crustaceen (Amphipoda und Cladocera) des Dnjepr. Russiche Hydrobiologisce Zeitschrift 1 (11-12):322-324.

Chernomor O, Haeseler A von, Minh BQ. 2016. Terrace aware data structure for phylogenomic inference from supermatrices. Systematic biology 65 (6):997-1008. 
880 Chiang S-c, Du NS. 1979. Crustacea: freshwater Cladocera. Peking: Science Press.

881 Cho KS, Mizuno T. 1977. Comparison of limnological conditions and plankton communities in the Uiam Lake consisting of the two different river systems. Korean Journal of Limnology 10 (3-4):73-85.

Clark JR, Ree RH, Alfaro ME, King MG, Wagner WL, Roalson EH. 2008. A comparative study in ancestral range reconstruction methods: retracing the uncertain histories of insular lineages. Systematic biology 57 (5):693-707.

Collado C, Fernando CH, Sephton D. 1984. The freshwater zooplankton of Central America and the Caribbean. In: Dumont HJ, Tundisi JG, eds. Tropical Zooplankton. Dordrecht: Springer Netherlands, 105-119.

Cornetti L, Fields PD, Van Damme K, Ebert D. 2019. A fossil-calibrated phylogenomic analysis of Daphnia and the Daphniidae. Molecular phylogenetics and evolution 137:250262.

Cox AJ, Hebert PDN. 2001. Colonization, extinction, and phylogeographic patterning in a freshwater crustacean. Molecular ecology 10 (2):371-386.

Daday E von. 1903. Eine neue Cladoceren-Gattung aus der Familie der Bosminiden. Zoologischer Anzeiger 26 (704):594-597.

897

898

899

900

901

902

903

904

905

906

907

908

909

910

911

912

913

914

915

916

917

Daday E von. 1905. Untersuchungen uber die Susswasser Mikrofauna Paraguays. Zoologica 44 (3-6): $1-374$.

Daday E von. 1908. Adatok Nemet-Kelet-Afrika edesvizi mikrofaunajanak iameretehez. Mathematikai es Termeszettudomanyi Ertesito, Budapest 26:(1): 1-42, 43-57; (2): 200-220; (3): 294-321; (4): 374-404, 405-421; (5): 455-474.

Darwin C. 1859. On the Origin of Species by means of Natural Selection, or the preservation of favoured races in the struggle for life. London: John Murray.

Dayrat B. 2005. Towards integrative taxonomy. Biological Journal of the Linnean Society 85 (3):407-415.

Drummond AJ, Bouckaert RR. 2015. Bayesian evolutionary analysis with BEAST2. Cambridge, United Kingdom: Cambridge University Press.

Drummond AJ, Suchard MA, Xie D, Rambaut A. 2012. Bayesian phylogenetics with BEAUti and the BEAST 1.7. Molecular biology and evolution 29 (8):1969-1973.

Du Nan-shan. 1973. Cladocera of China. Peking: Science Press.

Dumont HJ. 1981. Cladocera and free-living Copepoda from the Fouta Djalon and adjacent mountain areas in West Africa. Hydrobiologia 85 (2):97-115.

Dumont HJ. 1986. The Nile River system. In: Davies BR, Walker KF, eds. The Ecology of River Systems, vol. 60. Dordrecht: Springer Netherlands, 61-88.

Elias-Gutierrez M, Suarez Morales E, Gutierrez Aguirre M, Silva Briano M, Granados Ramirez JG, Garfias Espejo T. 2008. Cladocera y copepoda de las aguas continentales de Mexico: Guia ilustrada. Mexico City: Universidad Nacional Autonoma de Mexico. 
918

919

920

921

922

923

924

925

926

927

928

929

930

931

932

933

934

935

936

937

938

939

940

941

942

943

944

945

946

947

948

949

950

951

952

953

954

955

956

Fisher-Reid MC, Wiens JJ. 2011. What are the consequences of combining nuclear and mitochondrial data for phylogenetic analysis? Lessons from Plethodon salamanders and 13 other vertebrate clades. BMC evolutionary biology 11:P300.

Frey DG. 1962. Cladocera from the Eemian interglacial of Denmark. Journal of Paleontology 36 (6): 1133-1154.

Frey DG. 1982. Questions concerning cosmopolitanism in Cladocera. Archiv fur Hydrobiologie 93 (4):484-502.

Frey DG. 1987a. The non-cosmopolitanism of chydorid Cladocera: implications for biogeography and evolution. Rotterdam: A.A.Balkema.

Frey DG. 1987b. The taxonomy and biogeography of the Cladocera. Hydrobiologia 145 (1):517.

Fu YX. 1997. Statistical tests of neutrality of mutations against population growth, hitchhiking and background selection. Genetics 147 (2):915-925.

Garrigan D, Lewontin R, Wakeley J. 2010. Measuring the sensitivity of single-locus "neutrality tests" using a direct perturbation approach. Molecular biology and evolution 27 (1):73-89.

Gernhard T. 2008. The conditioned reconstructed process. Journal of theoretical biology 253 (4):769-778.

Greze BS. 1921. Microscopic fauna of the Volga River near Kostroma. Trudy Kostromskogo Nauchnogo Obschestva po Izucheniyu Mestnogo Kraya 27:3-12.

Greze BS. 1929. On the biology of oxbow lakes. 1. Zooplankton of lakes in valley of the Kostroma River. Trudy Kostromskogo Nauchnogo Obschestva po Izucheniyu Mestnogo Kraya 43:1-20.

Hailer F, Kutschera VE, Hallström BM, Klassert D, Fain SR, Leonard JA, Arnason U, Janke A. 2012. Nuclear genomic sequences reveal that polar bears are an old and distinct bear lineage. Science 336 (6079):344-347.

Heads MJ. 2012. Molecular panbiogeography of the tropics. Berkeley: University of California Press.

Hebert PDN, Cywinska A, Ball SL, deWaard JR. 2003. Biological identifications through DNA barcodes. Proceedings of the Royal Society of London. Series B, Biological sciences 270 (1512):313-321.

Heled J, Drummond AJ. 2010. Bayesian inference of species trees from multilocus data. Molecular biology and evolution 27 (3):570-580.

Hewitt G. 2000. The genetic legacy of the Quaternary ice ages. Nature 405 (6789):907-913.

Hoang DT, Chernomor O, Haeseler A von, Minh BQ, Le Vinh S. 2018. UFBoot2: Improving the ultrafast bootstrap approximation. Molecular biology and evolution 35 (2):518-522.

Hofmann W. 1984. Postglacial morphological variation in Bosmina longispina Leydig (Crustacea, Cladocera) from the Grober Ploner See (north Germany) and its taxonomic implications. Journal of Zoological Systematics and Evolutionary Research 22 (4):294-301. 
957

958

959

960

961

962

963

964

965

966

967

968

969

970

971

972

973

974

975

976

977

978

979

980

981

982

983

984

985

986

987

988

989

990

991

992

993

994

995

Hovmoller R, Pape T, Kallersjo M. 2002. The Palaeoptera problem: basal Pterygote phylogeny inferred from $18 \mathrm{~S}$ and $28 \mathrm{~S}$ rDNA sequences. Cladistics : the international journal of the Willi Hennig Society 18 (3):313-323.

Idris BAG. 1983. Freshwater zooplankton of Malaysia (Crustacea: Cladocera). Pertanian Malaysia: Perenbit University Press.Jeong H, Kotov AA, Lee W. 2014. Checklist of the freshwater Cladocera (Crustacea: Branchiopoda) of South Korea. Proceedings of the Biological Society of Washington 127 (1):216-228.

Jones G. 2017. Algorithmic improvements to species delimitation and phylogeny estimation under the multispecies coalescent. Journal of mathematical biology 74 (1-2):447-467.

Kalyaanamoorthy S, Minh BQ, Wong TKF, Haeseler A von, Jermiin LS. 2017. ModelFinder: Fast model selection for accurate phylogenetic estimates. Nature methods $\mathbf{1 4}$ (6):587-589.

Kapli P, Lutteropp S, Zhang J, Kobert K, Pavlidis P, Stamatakis A, Flouri T. 2017. Multirate Poisson tree processes for single-locus species delimitation under maximum likelihood and Markov chain Monte Carlo. Bioinformatics (Oxford, England) 33 (11):1630-1638.

Karabanov DP, Bekker EI, Shiel RJ, Kotov AA. 2018. Invasion of a Holarctic planktonic cladoceran Daphnia galeata Sars (Crustacea: Cladocera) in the Lower Lakes of South Australia. Zootaxa 4402 (1):136-148.

Katoh K, Rozewicki J, Yamada KD. 2019. MAFFT online service: Multiple sequence alignment, interactive sequence choice and visualization. Briefings in bioinformatics $\mathbf{2 0}$ (4):1160-1166.

Kim IH. 1988. Key to the Korean freshwater Cladocera. Korean journal of systematic zoology n.nspc.2 (Special Issue, 2):43-65.

Klocke E. 1903. Bosminopsis in Japan. Nebst Bemerkungen uber einige andere japanische Cladoceren und den Hakonesee. Annotationes Zoologicae Japonenses 4 (5):123-135.

Knowlton N, Weigt LA. 1998. New dates and new rates for divergence across the Isthmus of Panama. Proceedings of the Royal Society of London. Series B, Biological sciences 265 (1412):2257-2263.

Korinek V. 1984. Cladocera. In: Symoens J-J, ed. Hydrobiological Survey of Lake Bangweulu and Luapulu River Basin, vol. 13. Bruxelles: Cercle Hydrobiologique de Bruxelles, 1-117.

Korovchinsky NM. 2006. The Cladocera (Crustacea: Branchiopoda) as a relict group. Zoological journal of the Linnean Society 147 (1):109-124.

Korovchinsky NM. 2013. Cladocera (Crustacea: Branchiopoda) of South East Asia: history of exploration, taxon richness and notes on zoogeography. Journal of Limnology 72 (s2):109124.

Kotov AA. 1997a. Structure of thoracic limbs in Bosminopsis deitersi Richard, 1895 (Anomopoda, Branchiopoda). Hydrobiologia 360 (1-3):25-32.

Kotov AA. 1997b. Studies on the morphology and variability of Amazonian Bosminopsis deitersi Richard, 1895 (Anomopoda Bosminidae). Arthropoda selecta 6 (1-2):3-30. 
996

997

998

999

1000

1001

1002

1003

1004

1005

1006

1007

1008

1009

1010

1011

1012

1013

1014

1015

1016

1017

1018

1019

1020

1021

1022

1023

1024

1025

1026

1027

1028

1029

1030

1031

1032

1033

1034

Kotov AA. 2013. Morphology and phylogeny of the Anomopoda (Crustacea: Cladocera). Moscow: KMK Scientific press Ltd.

Kotov AA, Ferrari FD. 2010. The taxonomic research of Jules Richard on Cladocera (Crustacea: Branchiopoda) and his collection at the National Museum of Natural History, USA. Zootaxa 2551 (1):37-64.

Kotov AA, Garibian PG, Bekker EI, Taylor DJ, Karabanov DP. 2021. A new species group from the Daphnia curvirostris species complex (Cladocera: Anomopoda) from the eastern Palaearctic: taxonomy, phylogeny and phylogeography. Zoological journal of the Linnean Society 191:772-822.

Kotov AA, Korovchinsky NM. 2006. First record of fossil Mesozoic Ctenopoda (Crustacea, Cladocera). Zoological journal of the Linnean Society 146 (2):269-274.

Kotov AA, Taylor DJ. 2011. Mesozoic fossils (145 Mya) suggest the antiquity of the subgenera of Daphnia and their coevolution with chaoborid predators. BMC evolutionary biology 11:129.

Kotov AA, Van Damme K, Bekker EI, Siboualipha S, Silva-Briano M, Ortiz AA, de La Rosa RG, Sanoamuang L-O. 2013. Cladocera (Crustacea: Branchiopoda) of Vientiane province and municipality, Laos. Journal of Limnology 72 (s2):81-108.

Krasnodebski F. 1937. Wioslarki (Cladocera) Zahorynia (Polesie). Archiwum Hydrobiologii $i$ Rybactwa 10 (4):344-412.

Kukharskaya EV, Dolgin VN. 2009. Zooplankton of the Chulym River basin. Vestnik Tomskogo Gosudarstvennogo Universiteta 6 (84):141-145.

Kumar S, Stecher G, Li M, Knyaz C, Tamura K. 2018. MEGA X: Molecular Evolutionary Genetics Analysis across Computing Platforms. Molecular biology and evolution 35 (6): 1547-1549.

Leigh JW, Bryant D, Nakagawa S. 2015. POPART: full-feature software for haplotype network construction. Methods in ecology and evolution / British Ecological Society 6 (9):1110-1116.

Leschinskaya AS. 1962. Zooplankton and benthos of Obskaya Guba as a found source for the fish. Trudy Salekhardskogo Statsionara Uralskogo Otdeleniya AN USSR 2:1-76.

Liao H-Y, Cai C-Y, Shen Y-B, Sun X-Y, Huang D-Y. 2020. An Early Cretaceous branchiopod community in northeastern China: Discovery of daphniid (Cladocera: Anmopoda) ephippia in the early assemblage of the Jehol Biota. Cretaceous Research 113:104491.

Lieder U. 1996. Crustacea: Cladocera/Bosminidae. Susswasserfauna von Mitteleuropa 8 (23): $1-80$.

Linko A. 1901. Bosminopsis (J. Richard) im europaischen Russland. Zoologischer Anzeiger 24 (645):345-347.

Lohse K. 2009. Can mtDNA barcodes be used to delimit species? A response to Pons et al. (2006). Systematic biology 58 (4):439-42; discussion 442-4.

Manujlova EF. The cladocerans of fauna of the USSR. Moscow: Nauka. 
1035

1036

1037

1038

1039

1040

1041

1042

1043

1044

1045

1046

1047

1048

1049

1050

1051

1052

1053

1054

1055

1056

1057

1058

1059

1060

1061

1062

1063

1064

1065

1066

1067

1068

1069

1070

1071

1072

Mashiko K. 1953. Cladocera and Rotatoria of Central China (Studies of the freshwater plankton of Central China, III). The Science Reports of Kanazawa University 2 (1):49-73.

Matzke NJ. 2013. Probabilistic historical biogeography: New models for founder-event speciation, imperfect detection, and fossils allow improved accuracy and model-testing. Frontiers of biogeography 5 (4):242-248.

Matzke NJ. 2014. Model selection in historical biogeography reveals that founder-event speciation is a crucial process in Island Clades. Systematic biology 63 (6):951-970.

Meissner VI. 1902. Animal world of the Volga River near Saratov. Trudy Saratovskogo Obschestva Estestvoispitateley i Liubiteley Estestvoznaniya 3:1-70.

Meissner VI. 1903. Materials to the study of entomostracans of River Volga. Arbeiten der Biologishen Wolga-Station 1:159-201.

Mergeay J, Aguilera X, Declerck S, Petrusek A, Huyse T, Meester L de. 2008. The genetic legacy of polyploid Bolivian Daphnia: the tropical Andes as a source for the North and South American D. pulicaria complex. Molecular ecology 17 (7):1789-1800.

Michael RG, Sharma BK. 1988. Fauna of India and adjacent countries. Indian Cladocera (Crustacea: Branchiopoda: Cladocera). Calcutta: Zoological Survey of India.

Molloy EK, Warnow T. 2018. To include or not to include: The impact of gene filtering on species tree estimation methods. Systematic biology 67 (2):285-303.

Muller RD, Cannon J, Qin X, Watson RJ, Gurnis M, Williams S, Pfaffelmoser T, Seton M, Russell SHJ, Zahirovic S. 2018. GPlates: building a virtual Earth through deep time. Geochemistry, Geophysics, Geosystems 19 (7):2243-2261.

Muraveisky SD. 1924. Uber das tierische Plankton des Flusses Kerschenetz. Arbeiten der Biologishen Wolga-Station 7 (4-5):123-140.

Negrea S. 1983. Cladocera. In: Fauna Republicii Socialiste Romania. Volumul IV, CRUSTACEA. Fascicula 12. Bucuresti: Editura Academiei Republicii Socialiste Romania, 1399.

Nei M, Kumar S. 2000. Molecular evolution and phylogenetics. New York: Oxford University Press.

Neretina AN, Kotov AA, Van Damme K. 2019. A new case of false "wide" distribution for tropical cladocerans: the genus Notoalona Rajapaksa \& Fernando, 1987 (Crustacea: Cladocera) in the Old World. Zootaxa 4615 (3):489-510.

Nguyen L-T, Schmidt HA, Haeseler A von, Minh BQ. 2015. IQ-TREE: A fast and effective stochastic algorithm for estimating maximum-likelihood phylogenies. Molecular biology and evolution 32 (1):268-274.

Okonechnikov K, Golosova O, Fursov M. 2012. Unipro UGENE: a unified bioinformatics toolkit. Bioinformatics (Oxford, England) 28 (8):1166-1167.

Padial JM, La Riva I de. 2010. A response to recent proposals for integrative taxonomy. Biological Journal of the Linnean Society 101 (3):747-756. 
1073

1074

1075

1076

1077

1078

1079

1080

1081

1082

1083

1084

1085

1086

1087

1088

1089

1090

1091

1092

1093

1094

1095

1096

1097

1098

1099

1100

1101

1102

1103

1104

1105

1106

1107

1108

1109

1110

1111

1112

Pascual JAF, Rizo EZC, Han BP, Dumont HJ, Papa RDS. 2014. Taxonomy and distribution of four Cladoceran families (Branchiopoda: Cladocera: Moinidae, Bosminidae, Chydoridae and Sididae) in Philippine inland waters. The Raffles bulletin of zoology 62:771-794.

Pennak RW. 1953. Fresh-water invertebrates of the United States. New York: The Ronald Press Company.

Petlina AP, Yyrakova TV, Zalozniy NA, Bocharova TA, Lukjantseva LV, Podzhunas SS. 2000. Hydrobionts of small water currents of The Lower Tom Diver and their significance in the evaliation of the ecological state of water bodues. Sibirskii Ekologicheskii Zhurnal 3:323335.

Pirozhnikov PL. 1937. Zooplankton of the Yenisey River and Yenisey Bay and its role in the fish feeding. Trudy Vsesoyuznogo Arkticheskogo Instituta 98:1-61.

Pons J, Barraclough TG, Gomez-Zurita J, Cardoso A, Duran DP, Hazell S, Kamoun S, Sumlin WD, Vogler AP. 2006. Sequence-based species delimitation for the DNA taxonomy of undescribed insects. Systematic biology 55 (4):595-609.

Popova EV, Petrusek A, Kořínek V, Mergeay J, Bekker EI, Karabanov DP, Galimov YR, Neretina TV, Taylor DJ, Kotov AA. 2016. Revision of the Old World Daphnia (Ctenodaphnia) similis group (Cladocera: Daphniidae). Zootaxa 4161 (1):1-40.

Rahm U. 1956. Cladoceren aus den Regenwaldgebiet der Elfenbeinkuste. Verhandlungen der Naturforschenden Gesellschaft in Basel 67 (2):239-268.

Rambaut A, Drummond AJ, Xie D, Baele G, Suchard MA. 2018. Posterior summarization in Bayesian phylogenetics using Tracer 1.7. Systematic biology 67 (5):901-904.

Ramirez-Soriano A, Ramos-Onsins SE, Rozas J, Calafell F, Navarro A. 2008. Statistical power analysis of neutrality tests under demographic expansions, contractions and bottlenecks with recombination. Genetics 179 (1):555-567.

Rane P. 1984. A new species of the genus Bosminopsis (Crustacea: Cladocera: Bosminidae) from India. Journal of the Bombay Natural History Society 81 (3):668-669.

Reid NM, Carstens BC. 2012. Phylogenetic estimation error can decrease the accuracy of species delimitation: a Bayesian implementation of the general mixed Yule-coalescent model. BMC evolutionary biology 12:196.

Rey J, Vasquez E. 1986. Bosminopsis macaguensis n. sp. et Alona ovata n. sp. (Crustacea, Cladocera), Cladoceres nouveaux du Venezuela. Annales de Limnologie - International Journal of Limnology 22 (3):219-229.

Rey J, Vasquez E. 1989. Bosminopsis brandorffi n.sp. (Crustacea, Cladocera) une nouvelle espece de Bosminidae des systemes Amazone et Orenoque. Annales de Limnologie International Journal of Limnology 25 (3):215-218.

Richard J. 1895. Description d'un nouveau Cladocere, Bosminopsis deitersi, n. gen., n.sp. Bulletin de la Societe Zoologique de France 20:96-98.

Richard J. 1897. Entomostraces de l'Amerique du Sud, recueillis par MM. U. Deiters, H. von Ihering, G. W. Muller et C. O. Poppe. Memoires de la Societe zoologique de France 10:263301 . 
1113

1114

1115

1116

1117

1118

1119

1120

1121

1122

1123

1124

1125

1126

1127

1128

1129

1130

1131

1132

1133

1134

1135

1136

1137

1138

1139

1140

1141

1142

1143

1144

1145

1146

1147

1148

1149

1150

1151

Rogers DC, Kotov AA, Sinev AY, Glagolev SM, Korovchinsky NM, Smirnov NN, Bekker EI. 2019. Chapter 16.2. Arthropoda: Class Branchiopoda. In: Rogers CD, Thorp JH, eds. Thorp and Covich's Freshwater Invertebrates. Volume 4: Keys to Palaearctic Fauna. London: Academic Press, 643-724.

Rosen DE. 1978. Vicariant Patterns and Historical Explanation in Biogeography. Systematic zoology 27 (2):159-188.

Rozas J, Ferrer-Mata A, Sanchez-DelBarrio JC, Guirao-Rico S, Librado P, Ramos-Onsins SE, Sanchez-Gracia A. 2017. DnaSP 6: DNA sequence polymorphism analysis of large data sets. Molecular biology and evolution 34 (12):3299-3302.

Rylov VM. 1940. Vetvistousie rakoobraznie - Cladocerans (Cladocera). In: Zhadin VI, ed. Zhizn presnich vod. Moscow: Nauka, 331-357.

Sacherova V, Hebert PDN. 2003. The evolutionary history of the Chydoridae (Crustacea: Cladocera). Biological Journal of the Linnean Society 79 (4):629-643.

Sanoamuang L-O. 1997. Contributions to the knowledge of the Cladocera of north-east Thailand. Hydrobiologia 362 (1-3):45-53.

Schubart CD, Diesel R, Hedges SB. 1998. Rapid evolution to terrestrial life in Jamaican crabs. Nature 393 (6683):363-365.

Schwartz JH, Maresca B. 2006. Do molecular clocks run at all? A critique of molecular systematics. Biological theory 1 (4):357-371.

Schwarz G. 1978. Estimating the dimension of a model. The Annals of Statistics 6 (2):461-464.

Schwentner M, Clavier S, Fritsch M, Olesen J, Padhye S, Timms BV, Richter S. 2013. Cyclestheria hislopi (Crustacea: Branchiopoda): a group of morphologically cryptic species with origins in the Cretaceous. Molecular phylogenetics and evolution 66 (3):800-810.

Shimodaira H. 2002. An approximately unbiased test of phylogenetic tree selection. Systematic biology 51 (3):492-508.

Sinev AY, Karabanov DP, Kotov AA. 2020. A new North Eurasian species of the Alona affinis complex (Cladocera: Chydoridae). Zootaxa 4767 (1):115-137.

Skadowskiy SN. Some data on the biology of Bosminopsis zernowi Linko. Contributions to the studies of planknon of the Moscow River near Zvenigorod. Uchenije Zapiski Universiteta imeni A.L. Shaniavskogo. Trudy Biologicheskoy Laboratorii 1:1-62.

Skorikov AS, Bolokhontsev EN, Meissner VI. 1903. List of organisms found by Volga Biological Station in the area of its activity and identified to date (1900-1902). Ezhegodnik Volzhskoy Biologicheskoy Stantsii 1:20-47.

Smirnov NN. 1992. Mesozoic Anomopoda (Crustacea) from Mongolia. Zoological journal of the Linnean Society 104 (2):97-116.

Smirnov NN. 1995. Check-list of the Australian Cladocera (Crustacea). Arthropoda selecta 4 (1):3-6.

Smirnov NN, Kotov AA. 2018. On morphological radiation of Cladocera (Crustacea). Invertebrate Zoology 15 (3):231-248.

PeerJ reviewing PDF | (2021:01:57215:2:0:NEW 21 Mar 2021) 
1152 Smirnov NN, Timms BV. 1983. A revision of the Australian Cladocera (Crustacea). Records of

1153

1154

1155

1156

1157

1158

1159

1160

1161

1162

1163

1164

1165

1166

1167

1168

1169

1170

1171

1172

1173

1174

1175

1176

1177

1178

1179

1180

1181

1182

1183

1184

1185

1186

1187

1188

1189 the Australian Museum, Supplement 1:1-132.

Song HH, Mizuno T. 1982. Composition and characteristics of plankton community in Lake Ok-Jeong. Bulletin of the Korean Fisheries Society 15:333-344.

Stingelin T. 1904. Entomostracen, gesammelt von Dr. G. Hagmann in Mundungsgebiet des Amazonas. Zoologische Jahrbucher. Abteilung fur Systematik, Geographie und Biologie der Tiere 20 (6):575-590.

Suchard MA, Lemey P, Baele G, Ayres DL, Drummond AJ, Rambaut A. 2018. Bayesian phylogenetic and phylodynamic data integration using BEAST 1.10. Virus evolution 4 (1):vey016.

Sweet AD, Boyd BM, Allen JM, Villa SM, Valim MP, Rivera-Parra JL, Wilson RE, Johnson KP. 2018. Integrating phylogenomic and population genomic patterns in avian lice provides a more complete picture of parasite evolution. Evolution 72 (1):95-112.

Tajima F. 1989. Statistical method for testing the neutral mutation hypothesis by DNA polymorphism. Genetics 123 (3):585-595.

Tanaka S. 2000. A taxomonic revision of Japanese Bosminidae (Crustacea, Cladocera). Research Report of the Scientific and Cultural Center of Toyama City 23:109-125.

Tanaka S, Ohtaka A. 2010. Freshwater Cladocera (Crustacea, Branchiopoda) in Lake Tonle Sap and its adjacent waters in Cambodia. Limnology (Tokyo) 11 (2):171-178.

Tarbeev ML, Golubeva AV, Tarasova AF, Shurganova GV. 2011. Evaluation of water quality in small and mirrle rivers of Nizhegorodskoe Povolzhje based on analysis of indicator species of zooplankton. Voda: Khinija i Ecologija 10 (40):87-92.

Taylor DJ, Finston TL, Hebert PDN. 1998. Biogeography of a widespread freshwater crustacean : Pseudocongruence and cryptic endemism in the North American Daphnia laevis complex. Evolution 52 (6):1648-1670.

Trifinopoulos J, Nguyen L-T, Haeseler A von, Minh BQ. 2016. W-IQ-TREE: a fast online phylogenetic tool for maximum likelihood analysis. Nucleic acids research 44 (W1):W2325.

Ueno M. 1932. Contributions to the knowledge of the Cladocera fauna of China. Internationale Revue der gesamten Hydrobiologie und Hydrographie 27 (1-3):234-251.

Ueno M. 1937a. Cladocera of Manchoukuo. Internationale Revue der gesamten Hydrobiologie und Hydrographie 35 (1-6):199-216.

Ueno M. 1937b. Order Branchiopoda (Class Crustacea). Fauna Nipponica, Tokyo 9 (1):1-135.

Ueno M. 1940. Cladocera of Manchoukuo. Phyllopoda of Manchoukuo. In: Reports of Limnology Survey in Kwantung and Manchoukuo, Dairen. Kwantung: Kwantung Ministry of Civil, 323-367, 368-381.

Ueno M. 1944. Cladocera of the Yangtze Delta. (Reports on the limnological survey of Central China. XXIII). Journal of the Shanghai Science Institute 14 (5):399-418. 
1190

1191

1192

1193

1194

1195

1196

1197

1198

1199

1200

1201

1202

1203

1204

1205

1206

1207

1208

1209

1210

1211

1212

1213

1214

1215

1216

1217

1218

1219

1220

1221

1222

1223

1224

1225

1226

1227

1228

Vaidya G, Lohman DJ, Meier R. 2011. SequenceMatrix : Concatenation software for the fast assembly of multi-gene datasets with character set and codon information. Cladistics : the international journal of the Willi Hennig Society 27 (2):171-180.

Van Damme K, Kotov AA. 2016. The fossil record of the Cladocera (Crustacea: Branchiopoda): Evidence and hypotheses. Earth-Science Reviews 163:162-189.

Vawter L, Brown WM. 1986. Nuclear and mitochondrial DNA comparisons reveal extreme rate variation in the molecular clock. Science 234 (4773):194-196.

Vezhnovets VV. 2005. Crustaceans (Cladocera, Copepoda) in the water ecosystems of Belarus, a catalog and identification keys. Minsk: Belorusskaya Nauka.

Vitecek S, Kucinic M, Previsic A, Zivic I, Stojanovic K, Keresztes L, Balint M, Hoppeler F, Waringer J, Graf W, Pauls SU. 2017. Integrative taxonomy by molecular species delimitation: Multi-locus data corroborate a new species of Balkan Drusinae micro-endemics. BMC evolutionary biology 17 (1):129.

Watterson GA. 1975. On the number of segregating sites in genetical models without recombination. Theoretical Population Biology 7 (2):256-276.

Werestchagin GY. 1912. On fauna of Cladocera of European Russia. Trudy gidrobiologicheskoy stantsii na Glubokom ozere 4:121-132.

Werestchagin GY. 1913. The plankton of the Yamal Peninsula reservoirs. Annuaire du Musee Zoologique de l'Academie des Sciences St.-Petersburg 18 (2):169-220.

Wolski TB. 1932. Bosminopsis deitersi Richard, eine fur Polen neue Cladoceren-Art. Fragmenta Faunistica Musei Zoologici Polonici 1 (16):439-447.

Womack T, Slater BJ, Stevens LG, Anderson LI, Hilton J. 2012. First cladoceran fossils from the Carboniferous: Palaeoenvironmental and evolutionary implications. Palaeogeography, Palaeoclimatology, Palaeoecology 344-345:39-48.

Xiang X-F, Ji G-H, Chen S-Z, Yu G-L, Xu L, Han B-P, Kotov AA, Dumont HJ. 2015. Annotated Checklist of Chinese Cladocera (Crustacea: Branchiopoda). Part I. Haplopoda, Ctenopoda, Onychopoda and Anomopoda (families Daphniidae, Moinidae, Bosminidae, Ilyocryptidae). Zootaxa 3904 (1):1-27.

Xu S, Hebert PDN, Kotov AA, Cristescu ME. 2009. The noncosmopolitanism paradigm of freshwater zooplankton: Insights from the global phylogeography of the predatory cladoceran Polyphemus pediculus (Linnaeus, 1761) (Crustacea, Onychopoda). Molecular ecology 18 (24):5161-5179.

Yang L, Tan Z, Wang D, Xue L, Guan M-X, Huang T, Li R. 2014. Species identification through mitochondrial rRNA genetic analysis. Scientific reports 4:4089.

Yoon SM. 2010. Arthropoda: Branchiopoda: Anostraca, Notostraca, Spinicaudata, Laevicaudata, Ctenopoda, Anomopoda, Haplopoda Branchiopods. Invertebrate fauna of Korea 21 (2):1156.

Yoon SM, Kim HS. 1987. A systematic study on the freshwater Cladocera from Korea. Korean journal of systematic zoology 3 (2):175-207.

Peer) reviewing PDF | (2021:01:57215:2:0:NEW 21 Mar 2021) 
1229 Yu Y, Harris AJ, Blair C, He X. 2015. RASP (Reconstruct Ancestral State in Phylogenies): A tool for historical biogeography. Molecular phylogenetics and evolution 87 (1):46-49.

Zernov SA. 1901. Note on zooplankton of rivers Shoshma and Vyatka Malmyzhskoho uezda Vyatskoj gubernii. Dnevnik Zoologicheskogo Otdeleniya Imperatorskogo Obshchestva Lubiteley Estestvoznaniya, Antropologii i Etnografii 3 (2):4-36.

Zhang J, Kapli P, Pavlidis P, Stamatakis A. 2013. A general species delimitation method with applications to phylogenetic placements. Bioinformatics (Oxford, England) 29 (22):28692876.

Zykoff W. 1906. Bosminopsis in Centralrussland. Zoologischer Anzeiger 30 (1-2):22-24. 


\section{Captions to figures}

1242

to two major phylogroups: B. zernowi (red rectangles) and Bosminopsis sp. (blue rectangle).

1245

Visualisation of the localities was made in free software DIVA-GIS7.5.0 (https:/www.divagis.org) using Open Access spatial GIS data from http://www.naturalearthdata.com as the layers.

1247

1248

1249

1250

1251

1252

1253

1254

1255

1256

1257

1258

1259

1260

1261

1262

1263

1264

Fig. 1. Distribution of studied populations of the Bosminopsis deitersi group belonging

summary of results of the cybertaxonomic species delimitation by different methods.

Analyses referring are based on mitochondrial (mit.), nuclear (nuc.) and multi-locus datasets

(STACEY). Node supports are: UFboot2 (ML) and posterior probabilities (BI), in percent for mitochondrial genes in the numerator and nuclear genes in the denominator. Dashes indicate branches that were not supported by a method.

\section{Fig. 3. A haplotype $16 S$ network for Bosminopsis zernowi.}

Fig. 4. Biogeographic history of B. deitersi group. A - a possible phylogenetic tree for four loci based on the strict molecular clock, speciation by Yule process. Alternative topology of mitochondrial tree is represented by dotted line. Stratigraphic chart according to the International Commission on Stratigraphy (https://stratigraphy.org/chart). B - a proposed biogeographic history of the $B$. deitersi group on the consensus mitochondrial tree combined with the result of DIVALAKE $+\mathrm{J}$ model. Only tree topology is represented. Pie charts in each node demonstrate probabilities of alternative ancestral ranges; the most probable range is marked by the letter in the center. C - Possible ancestral ranges on palaeo-maps are represented at: 198 MYA, 72 MYA 
1265 and 5 MYA. The maps are from the PalaeoAtlas for GPlates free software under GNU - General

1266 Public License (GPL) Ver. 2 (http://www.gnu.org/licenses/old-licenses/gpl-2.0.html).

1267

1268

Fig. 5. Bosminopsis deitersi Richard, 1895 from Brazil (A-E) and Bosminopsis sp.

1269

1270

from Bung Pueng, Kalasin Province (F) and Lake Bueng Khong Long, Nong Khai Province

(G-H) in Thailand (F-H). A, Adult parthenogenetic female from Rio Xingu. B-D, Ephippial

1271

female from Lago do Castanho, lateral, dorsal and anterior view. E, Juvenile female from Rio

1272

1273

Tapajos. F. Large adult parthenogenetic female. G-H, Juvenile female and its mucro. Scale bars:

$\mathrm{A}-\mathrm{G}=0.1 \mathrm{~mm}, \mathrm{H}=0.01 \mathrm{~mm}$.

1274

1275

Fig. 6. Bosminopsis deitersi Richard, 1895, parthenogenetic (A-I) and ephippial (J-K)

1276

females from Lago do Castanho and Lago Cristalino, both in Amazonas, Brazil. A, Adult

1277

parthenogenetic female, lateral view. B, Its head, lateral view. C-D, Head, anterior view. E,

1278

Postero-ventral portion of valve. F-G, Posteroventral portion of valve. H, Antenna I. I, Antenna

1279

II. J, Mature ephippial female, lateral view. K, Mature ephippial female, dorsal view. Scale bars

1280

$=0.1 \mathrm{~mm}$.

1281

1282

Fig. 7. Bosminopsis deitersi Richard, 1895, parthenogenetic female from Lago do

1283

Castanho, Amazonas, Brazil. A-C, Postabdomen, lateral view. D, Limb I. E, Limb II. F, Limb

1284

III. G, Gnathobase of limb III. H, Limb IV. I, Limb V. Scale bar $=0.1 \mathrm{~mm}$.

1285

1286

Fig. 8. Bosminopsis deitersi Richard, 1895, juvenile male from Lago do Castanho

1287

(Amazonas, Brazil). A-B, Lateral view. C, Head, lateral view. D, Head, anterior view. E-F, 
1288 Antero-ventral portion of valve. G-H, Postero-ventral portion of valve. I-J, Postabdomen. K-M, 1289 Limb I. Scale bars $=0.1 \mathrm{~mm}$.

1290

1291

1292

1293

1294

1295

1296

1297

1298

1299

1300

1301

1302

1303

1304

1305

1306

1307

1308 Its dorsal view. Scale bars $=0.1 \mathrm{~mm}$.

1309

1310

1311

Fig. 11. Bosminopsis zernowi Linko, 1901, large parthenogenetic females from

Ivankovskoe Water Reservoir on Volga River, European Russia (A-J) and mature ephippial female from a tributary of Dnepr River, Ukraine (K-L). A-B, Lateral view. C, Head, lateral view. D, Head, anterior view. E, Setae at antero-ventral valve portion. F-H, Spines at postero-ventral valve margin. I, Antenna I. J, Antenna II. K, Ephippial female, lateral view. L,

Fig. 12. Bosminopsis zernowi Linko, 1901, parthenogenetic female Ivankovskoe Water Reservoir on Volga River, Tver' Area, European Russia. A-C, Postabdomen. D, Limb I. E, 
1312 Ejector hooks I. F, Limb II. G, Distal armature of its gnathobase. H, Limb III. I, Its inner-distal

1313 portion. J, Granthobase III. K, Limb IV. L, Its inner-distal portion. M, Limb V. Scale bar $=0.1$

$1314 \mathrm{~mm}$.

1315

1316

Fig. 13. Bosminopsis zernowi Linko, 1901, juvenile male of instar II (A, C-G, I, K) and

1317

1318

1319

1320

1321

1322

1323

1324

1325

1326

1327

1328

1329

1330
Fig. 14. Bosminopsis zernowi Linko, 1901, adult male from Lake Livadijskoe,

Primorski Territory, Far East of Russia. A, Lateral view. B, Head, lateral view. C, Its anterior view. D, Valve antero-ventral portion. E, Posterior portion of valve. F, Postabdomen. G, Antenna I. H. Antenna II. I, Limb I. Scale bars $=0.1 \mathrm{~mm}$.

Fig. 15. Schematic representation of distribution of two major morphotypes of the juvenile parthenogenetic female: with several mucro-like spines (red) and a single mucro (blue). Visualisation was made in free software DIVA-GIS7.5.0 using free spatial GIS data from (http://www.naturalearthdata.com) as the layers. Symbols are inserted manually. 


\section{Captions to supplements}

1332

1333

Supplementary Table S1. Source information.

1334

1335

Supplementary Table S2. Models of nucleotide substitutions.

1336

1337

Supplementary Figure S1. ML tree (based on IQ-TREE algorithm) for mitochondrial (A),

1338

nuclear (B) and full (C) datasets. Branches with support more than 0.7 are bold, while with lower

1339

support - thin. Asterisks mark conflicts where taxa were placed in subclade 1 in the

1340

mitochondrial tree and subclade 2 in nuclear tree.

1341

1342 
Figure 1

Distribution of studied populations of the Bosminopsis deitersi group belonging to two major phylogroups: B. zernowi (red rectangles) and Bosminopsis sp. (blue rectangle).

Visualisation of the localities was made in free software DIVA-GIS7.5.0 (

https://www.diva-gis.org ) using Open Access spatial GIS data from

http://www.naturalearthdata.com as the layers.

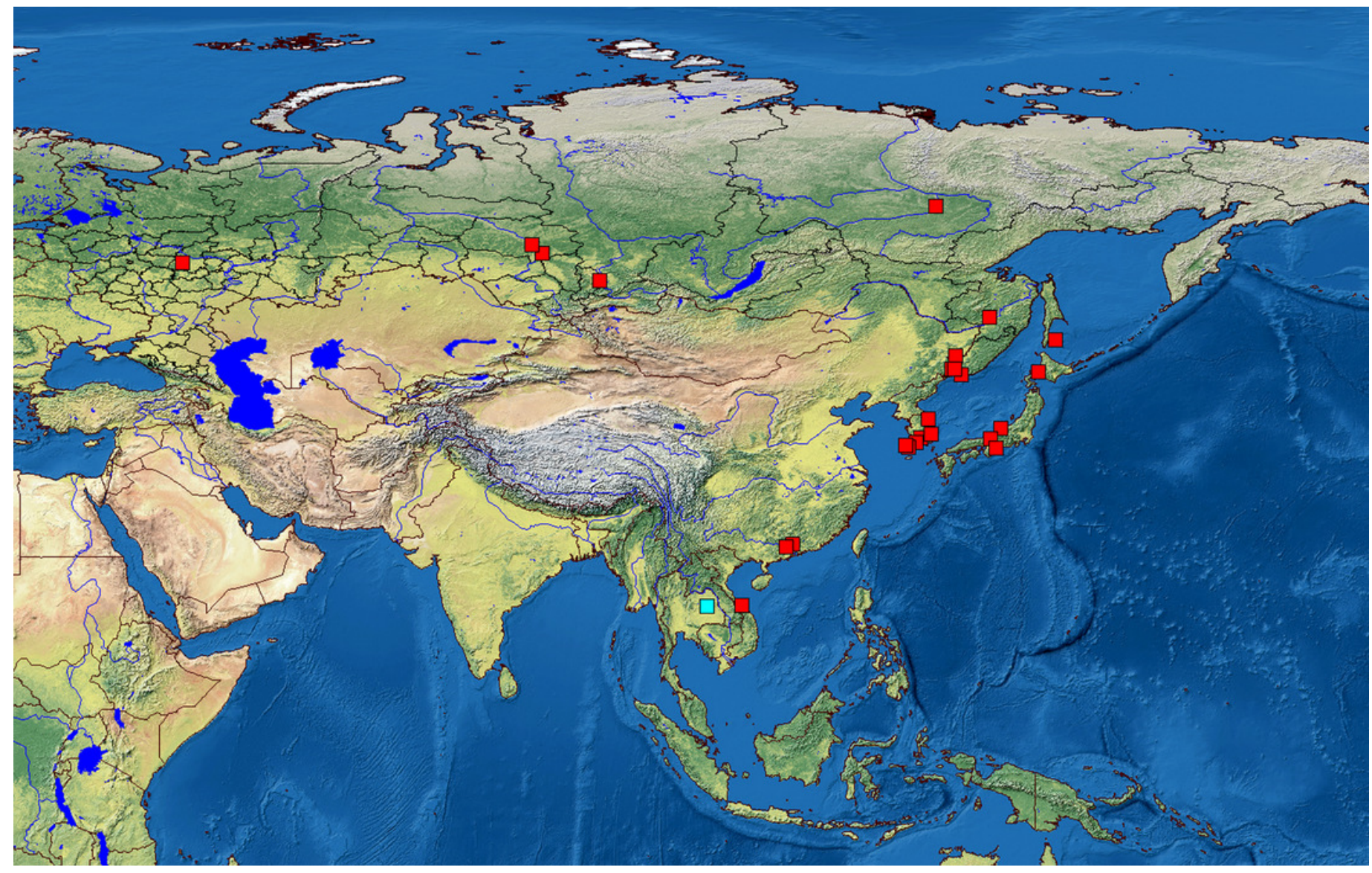




\section{Figure 2}

BI multi-locus tree based on the $\mathrm{COI}+16 \mathrm{~S}+18 \mathrm{~S}+28 \mathrm{~S}$ sequences, with a summary of results of the cybertaxonomic species delimitation by different methods.

Analyses referring are based on mitochondrial (mit.), nuclear (nuc.) and multi-locus datasets (STACEY). Node supports are: UFboot2 (ML) and posterior probabilities (BI), in percent for mitochondrial genes in the numerator and nuclear genes in the denominator. Dashes indicate branches that were not supported by a method. 


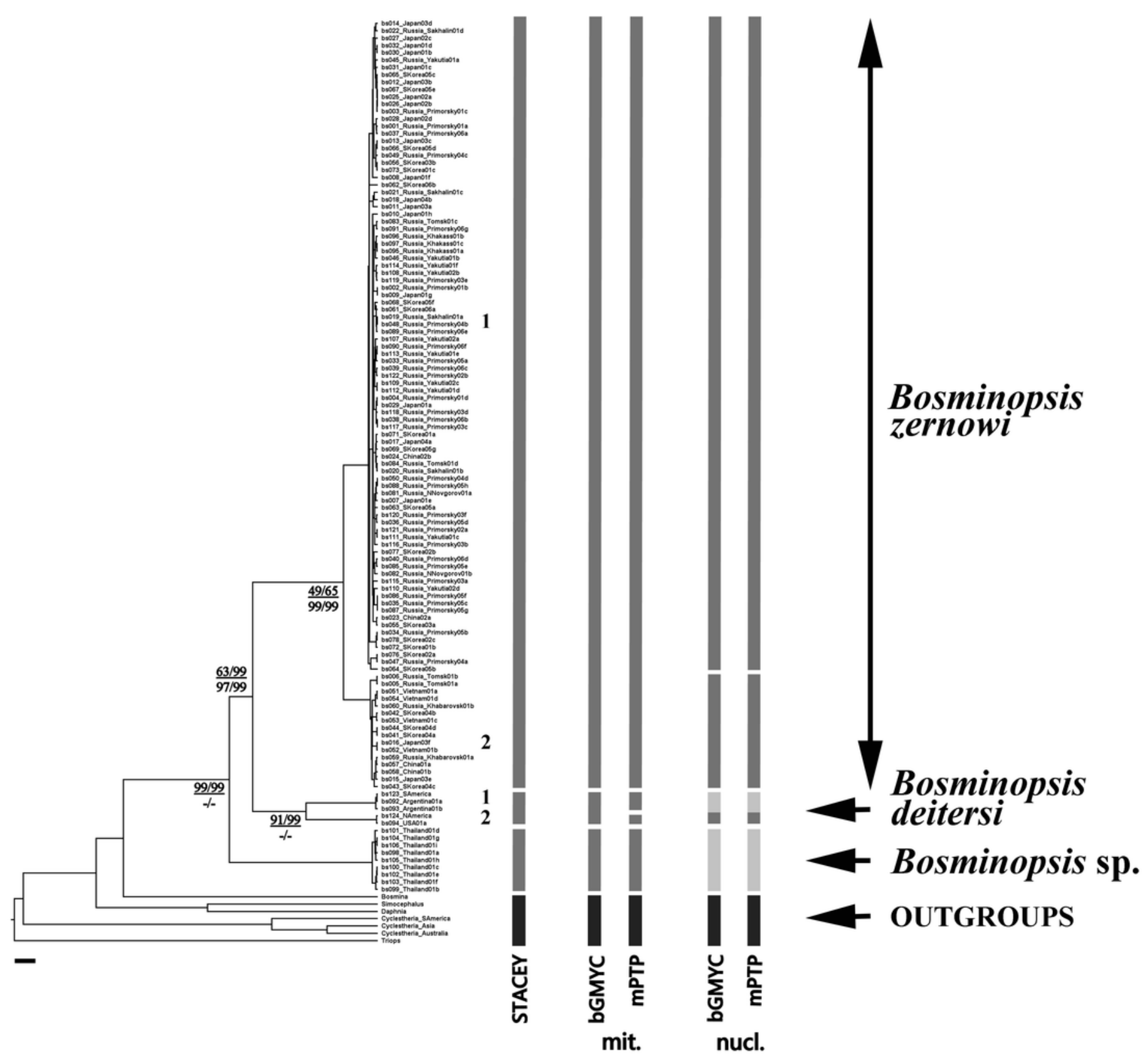


Figure 3

A haplotype 165 network for Bosminopsis zernowi.

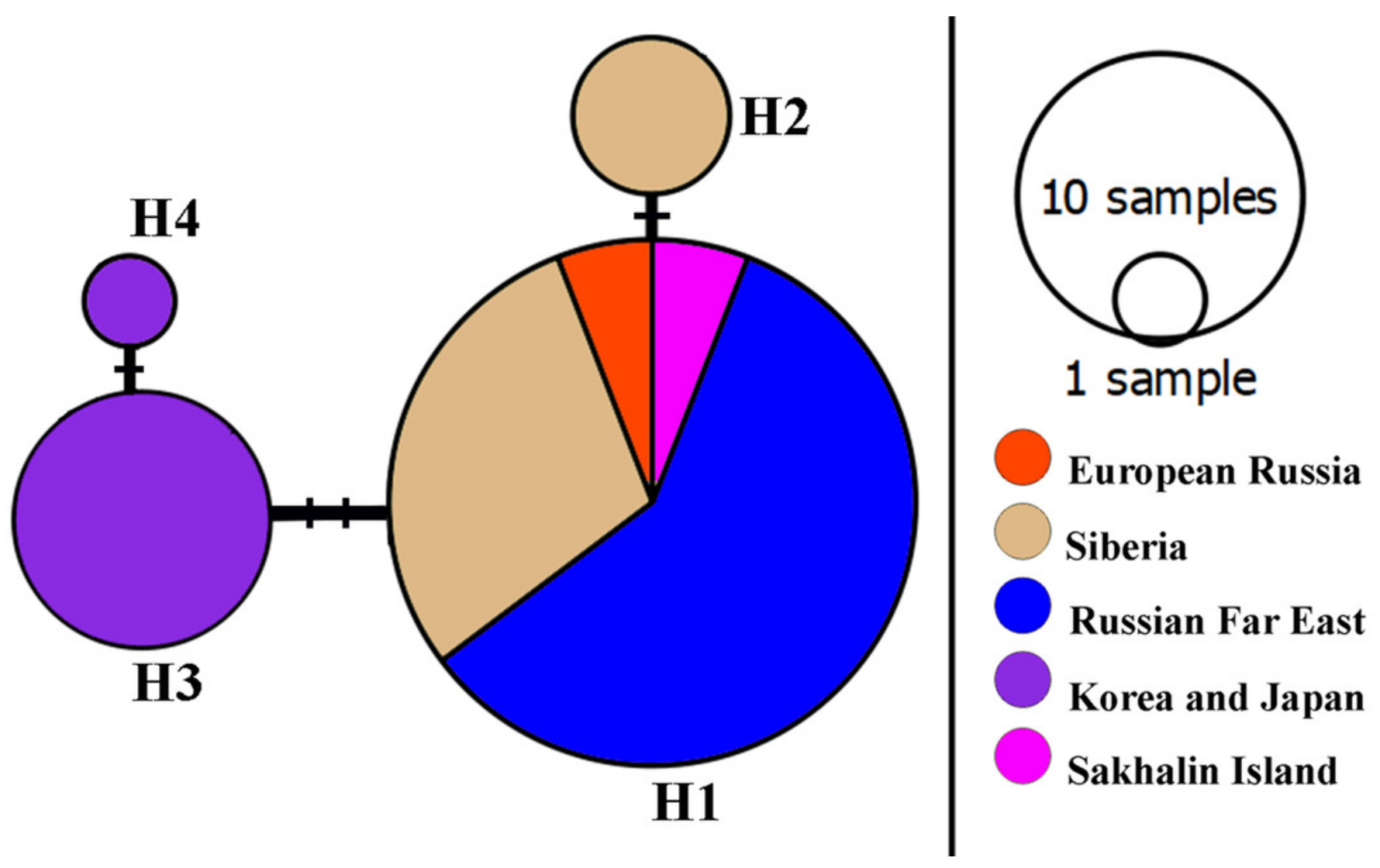




\section{Figure 4}

Biogeographic history of $B$. deitersi group.

A - a possible phylogenetic tree for four loci based on the strict molecular clock, speciation by Yule process. Alternative topology of mitochondrial tree is represented by dotted line. Stratigraphic chart according to the International Commission on Stratigraphy ( https://stratigraphy.org/chart ). B - a proposed biogeographic history of the B. deitersi group on the consensus mitochondrial tree combined with the result of DIVALAKE+J model. Only tree topology is represented. Pie charts in each node demonstrate probabilities of alternative ancestral ranges; the most probable range is marked by the letter in the center. $\mathrm{C}$ - Possible ancestral ranges on palaeo-maps are represented at: 198 MYA, 72 MYA and 5 MYA. The maps are from the PalaeoAtlas for GPlates free software under GNU - General Public License (GPL) Ver. 2 ( http://www.gnu.org/licenses/old-licenses/gpl-2.0.html ). 

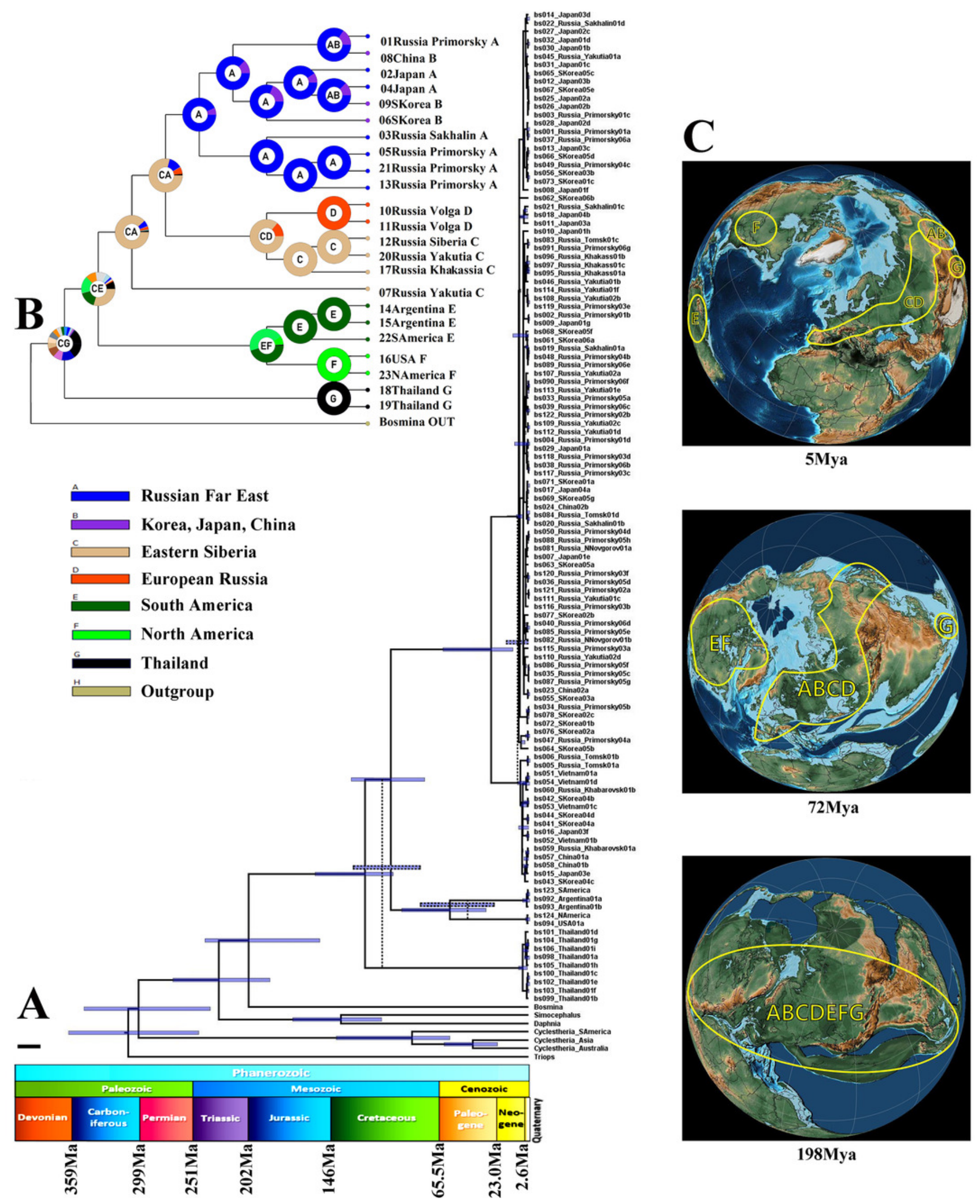

72Mya

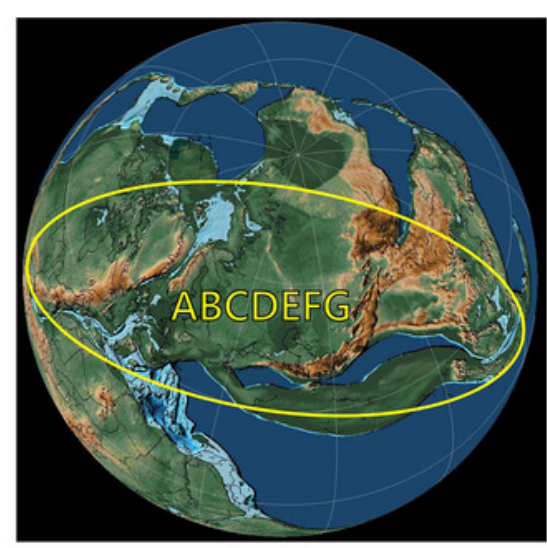

198Mya 


\section{Figure 5}

Fig. 5. Bosminopsis deitersi Richard, 1895 from Brazil (A-E) and Bosminopsis sp. from Bung Pueng, Kalasin Province (F) and Lake Bueng Khong Long, Nong Khai Province $(\mathrm{G}-\mathrm{H})$ in Thailand (F-H).

A, Adult parthenogenetic female from Rio Xingu. B-D, Ephippial female from Lago do Castanho, lateral, dorsal and anterior view. E, Juvenile female from Rio Tapajos. F. Large adult parthenogenetic female. $\mathrm{G}-\mathrm{H}$, Juvenile female and its mucro. Scale bars: $\mathrm{A}-\mathrm{G}=0.1$ $\mathrm{mm}, \mathrm{H}=0.01 \mathrm{~mm}$. 


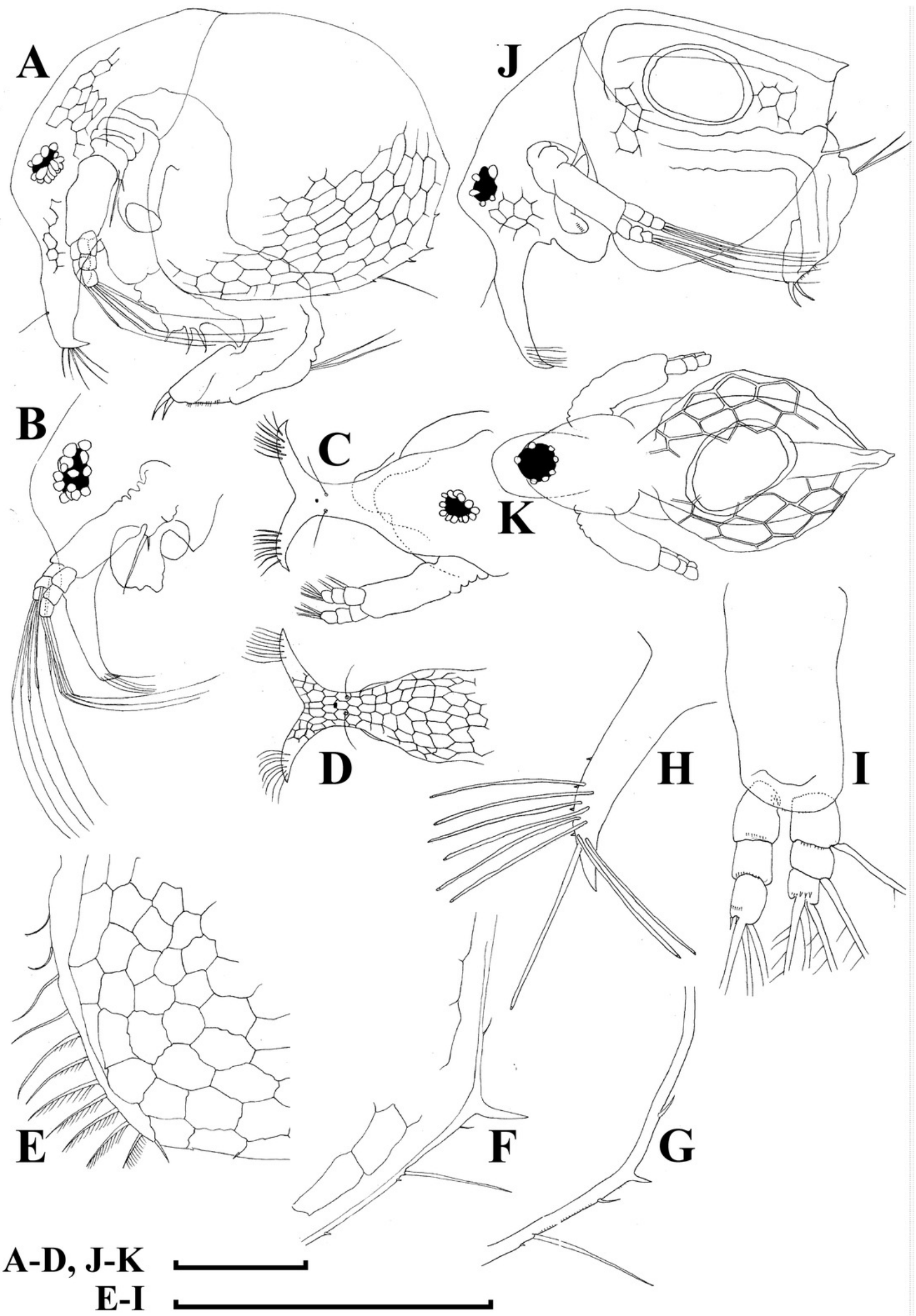




\section{Figure 6}

Bosminopsis deitersi Richard, 1895, parthenogenetic (A-I) and ephippial (J-K) females from Lago do Castanho and Lago Cristalino, both in Amazonas, Brazil.

A, Adult parthenogenetic female, lateral view. B, Its head, lateral view. C-D, Head, anterior view. E, Postero-ventral portion of valve. F-G, Posteroventral portion of valve. H, Antenna I. I, Antenna II. J, Mature ephippial female, lateral view. K, Mature ephippial female, dorsal view. Scale bars $=0.1 \mathrm{~mm}$. 


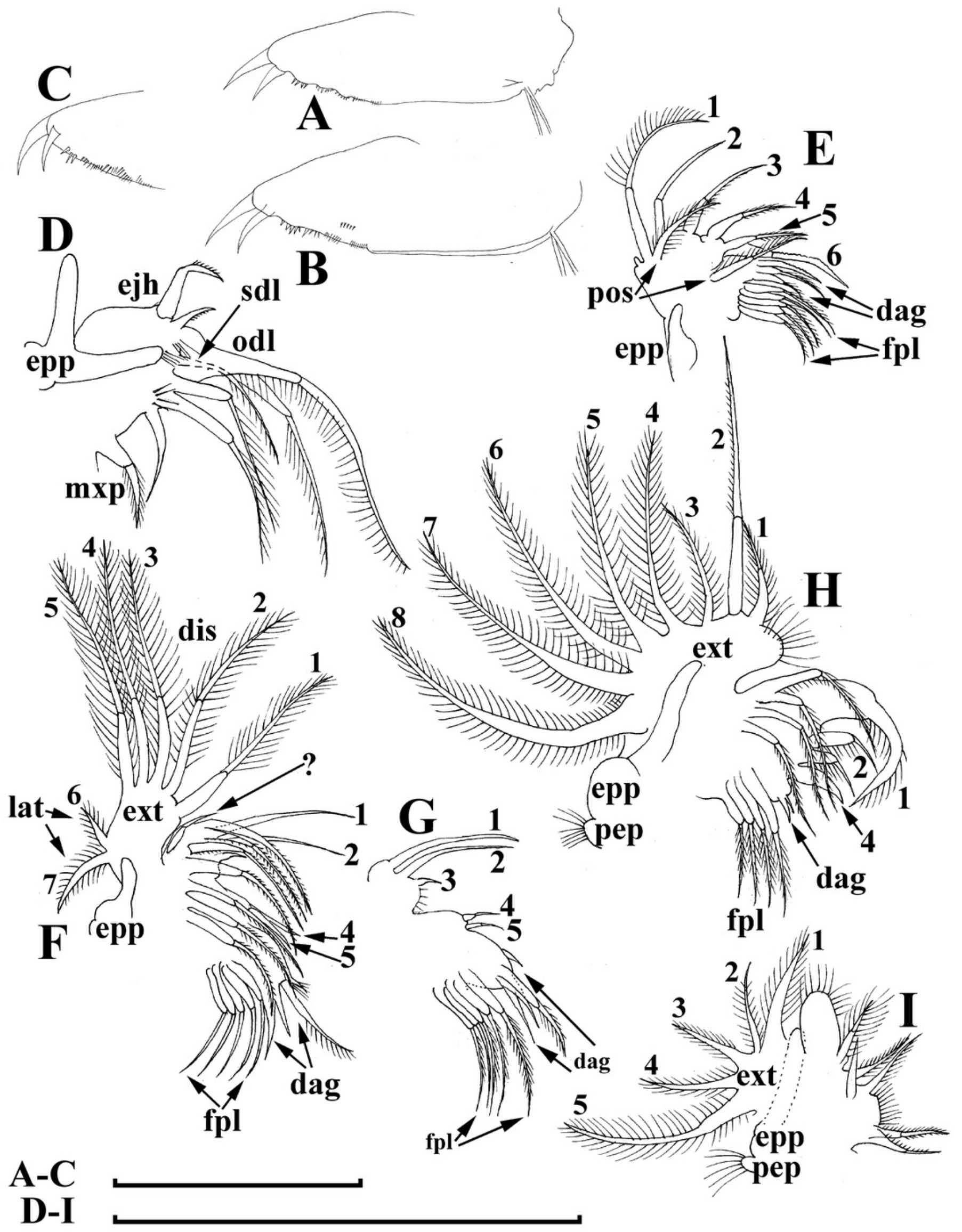


Figure 7

Bosminopsis deitersi Richard, 1895, parthenogenetic female from Lago do Castanho, Amazonas, Brazil.

A-C, Postabdomen, lateral view. D, Limb I. E, Limb II. F, Limb III. G, Gnathobase of limb III. H, Limb IV. I, Limb V. Scale bar $=0.1 \mathrm{~mm}$. 


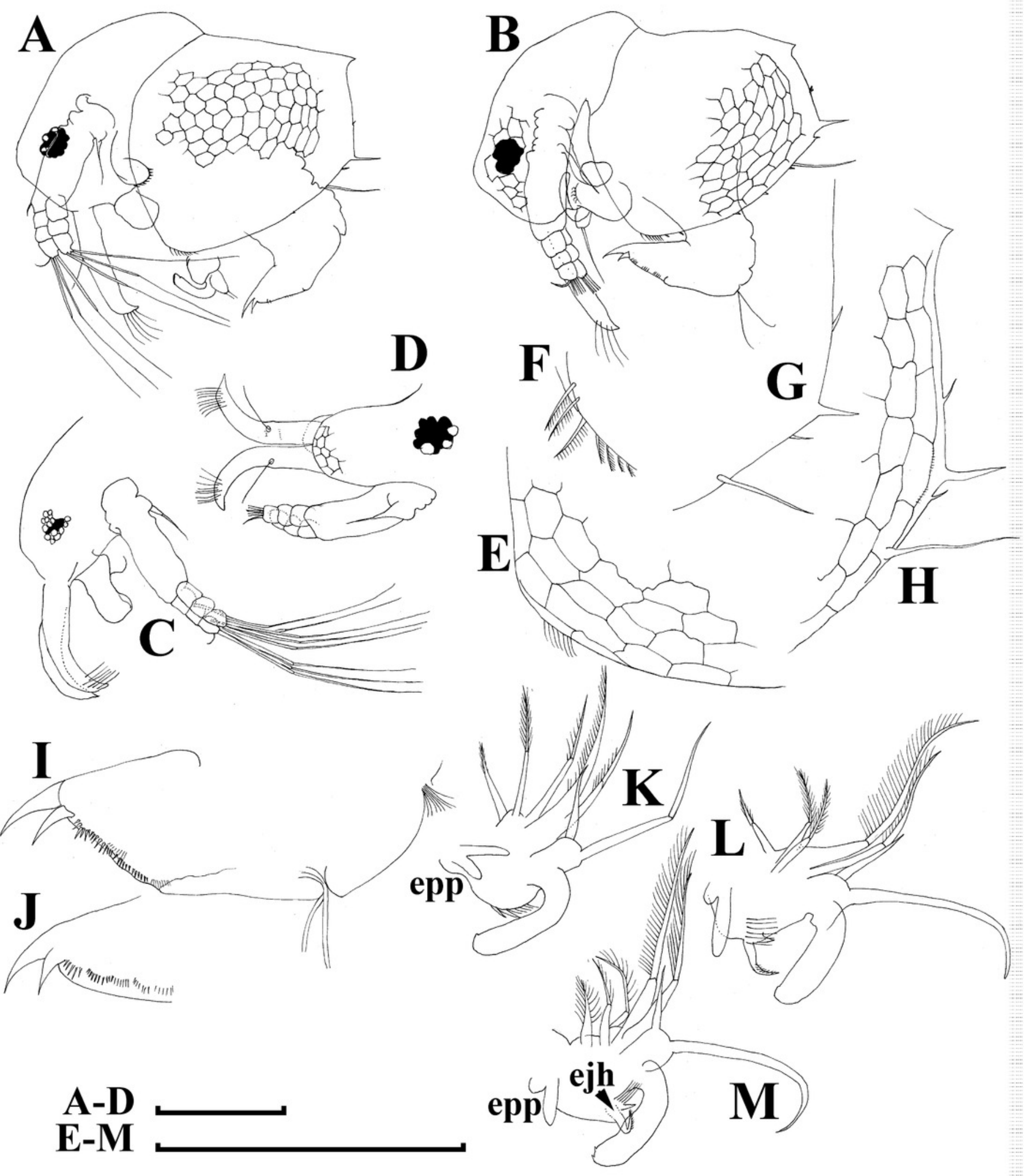


Figure 8

Bosminopsis deitersi Richard, 1895, juvenile male from Lago do Castanho (Amazonas, Brazil).

A-B, Lateral view. C, Head, lateral view. D, Head, anterior view. E-F, Antero-ventral portion of valve. G-H, Postero-ventral portion of valve. I-J, Postabdomen. K-M, Limb I. Scale bars $=0.1$ $\mathrm{mm}$. 


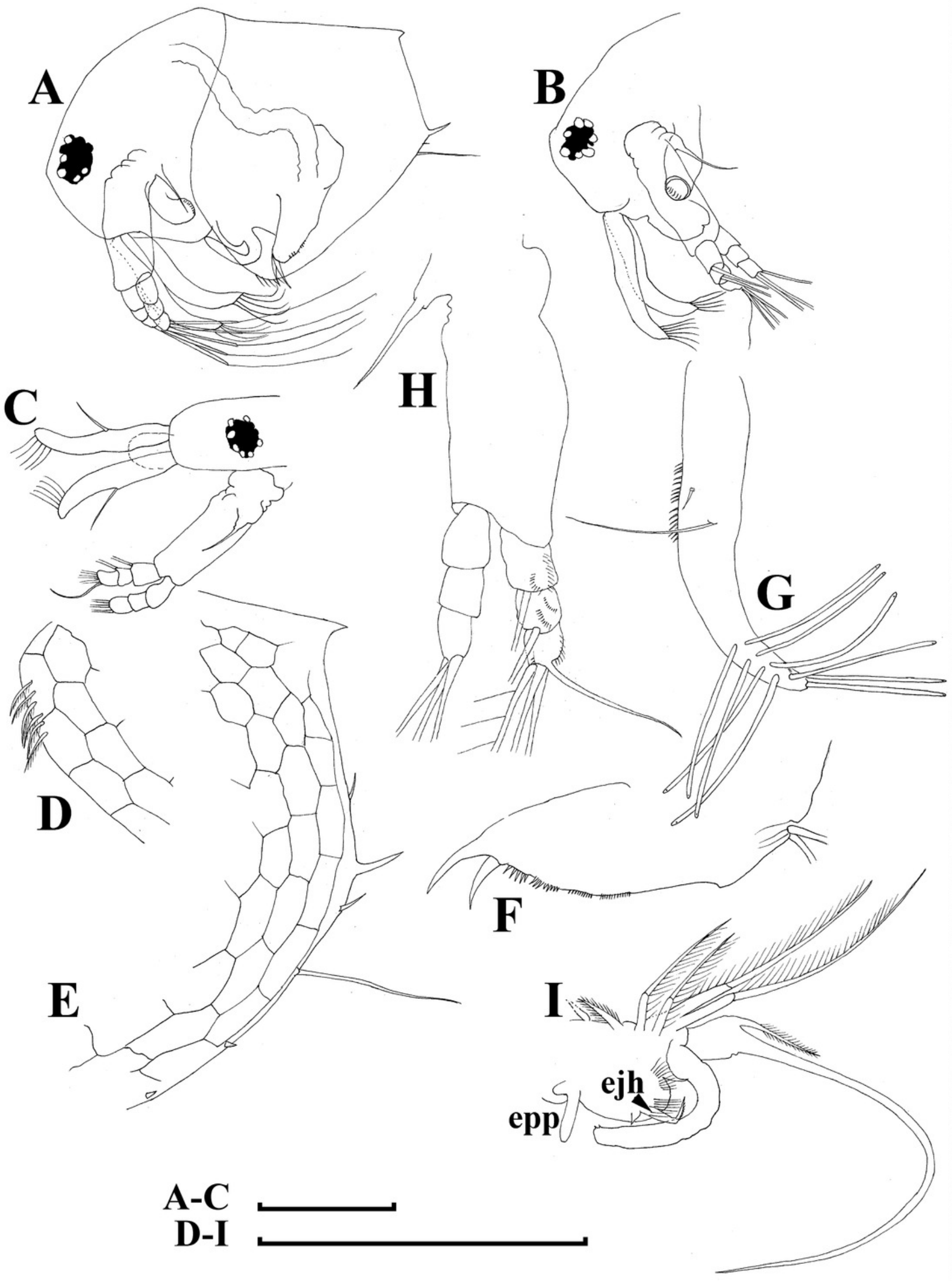


Figure 9

Bosminopsis deitersi Richard, 1895, adult male from Lago do Castanho, Amazonas, Brazil.

A-B, Lateral view. C, head, anterior view. D, Antero-ventral portion of valve. E, Postero-

ventral portion of valve. F, Postabdomen. G, Antenna I. H, Antenna II. I, Limb I. Scale bars = $0.1 \mathrm{~mm}$. 

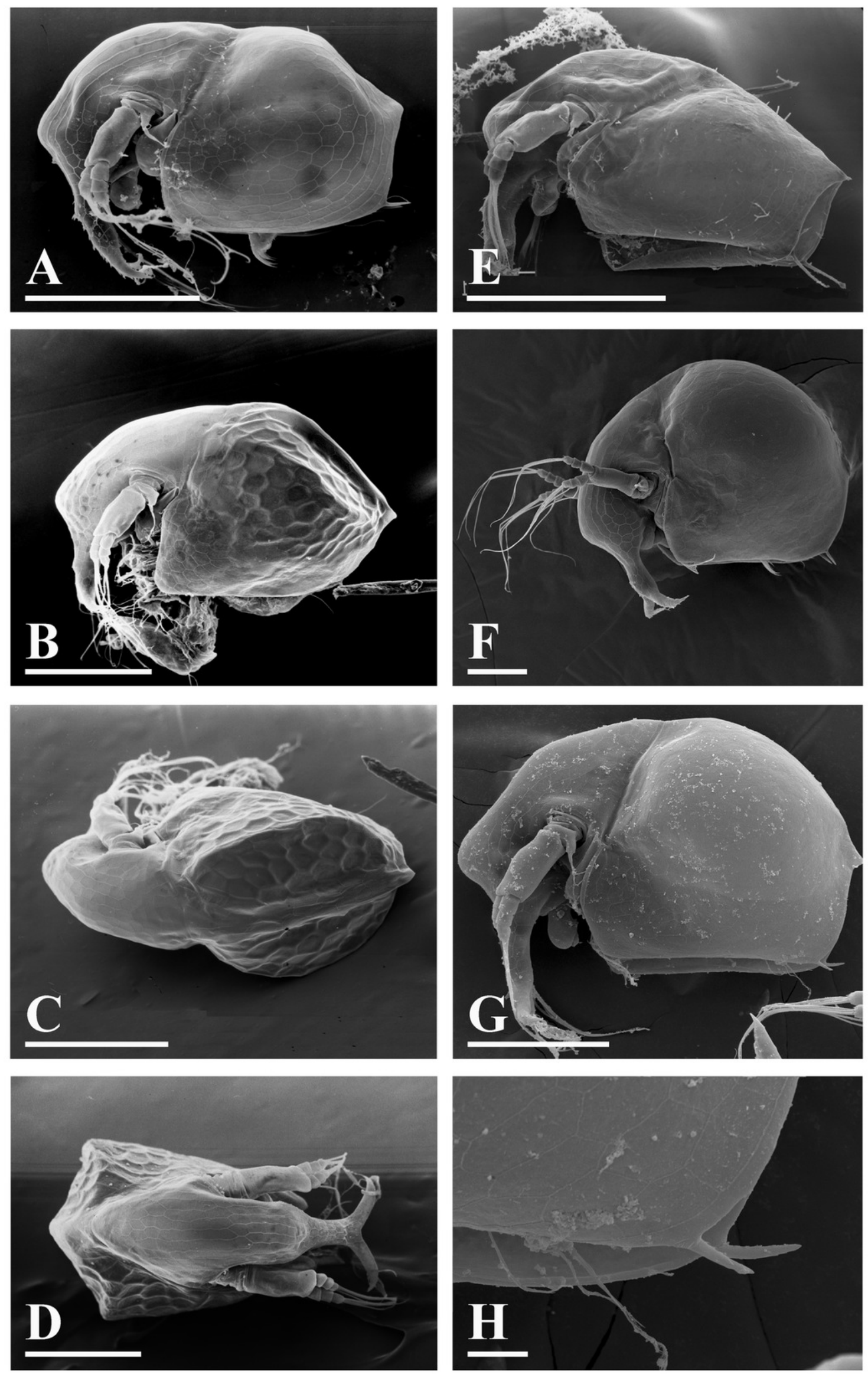

Peer] reviewing PDF | (2021:01:57215:2:0:NEW 21 Mar 2021) 


\section{Figure 10}

Bosminopsis zernowi Linko, 1900 from Sai-no-Kami Ike, Japan (A, C, G), Lake Ilinskoe, Primorsky Territory, Russia (B, D, F, H) and Lena River near Yakutsk, Yakutia Republic, Russia (E).

A, Adult parthenogenetic female. B-D, Ephippial female in lateral and dorsal view and sculpture of ephippium. E, Pre-ephippial female. F-G, Juvenile female; $H$, Juvenile male II. Scale bars: A-C, E-H $=0.1 \mathrm{~mm}, \mathrm{D}=0.01 \mathrm{~mm}$. 

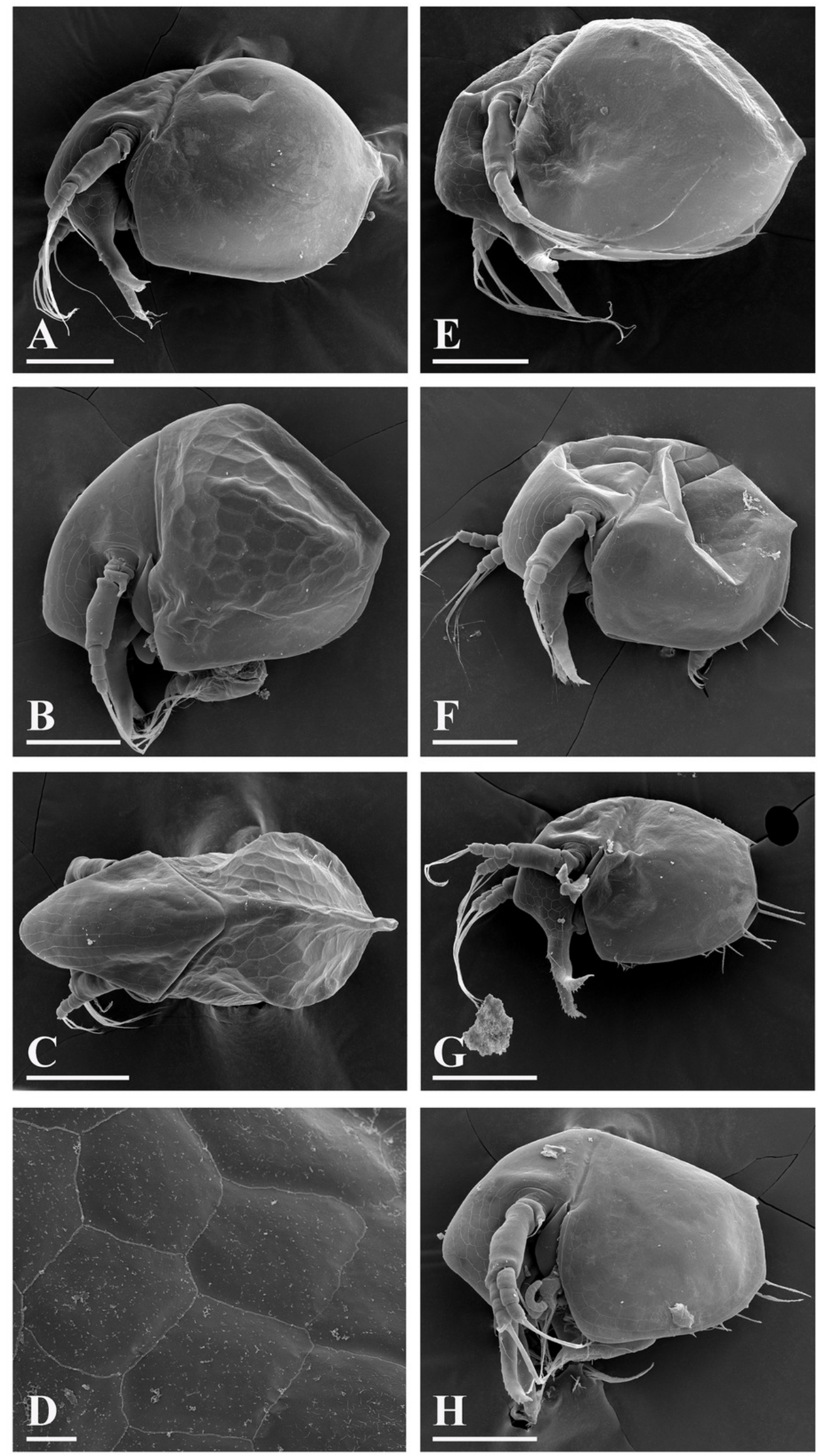

Peer) reviewing PDF | (2021:01:57215:2:0:NEW 21 Mar 2021) 


\section{Figure 11}

Bosminopsis zernowi Linko, 1901, large parthenogenetic females from Ivankovskoe Water Reservoir on Volga River, European Russia (A-J) and mature ephippial female from a tributary of Dnepr River, Ukraine (K-L).

A-B, Lateral view. C, Head, lateral view. D, Head, anterior view. E, Setae at antero-ventral valve portion. F-H, Spines at postero-ventral valve margin. I, Antenna I. J, Antenna II. K, Ephippial female, lateral view. L, Its dorsal view. Scale bars $=0.1 \mathrm{~mm}$. 


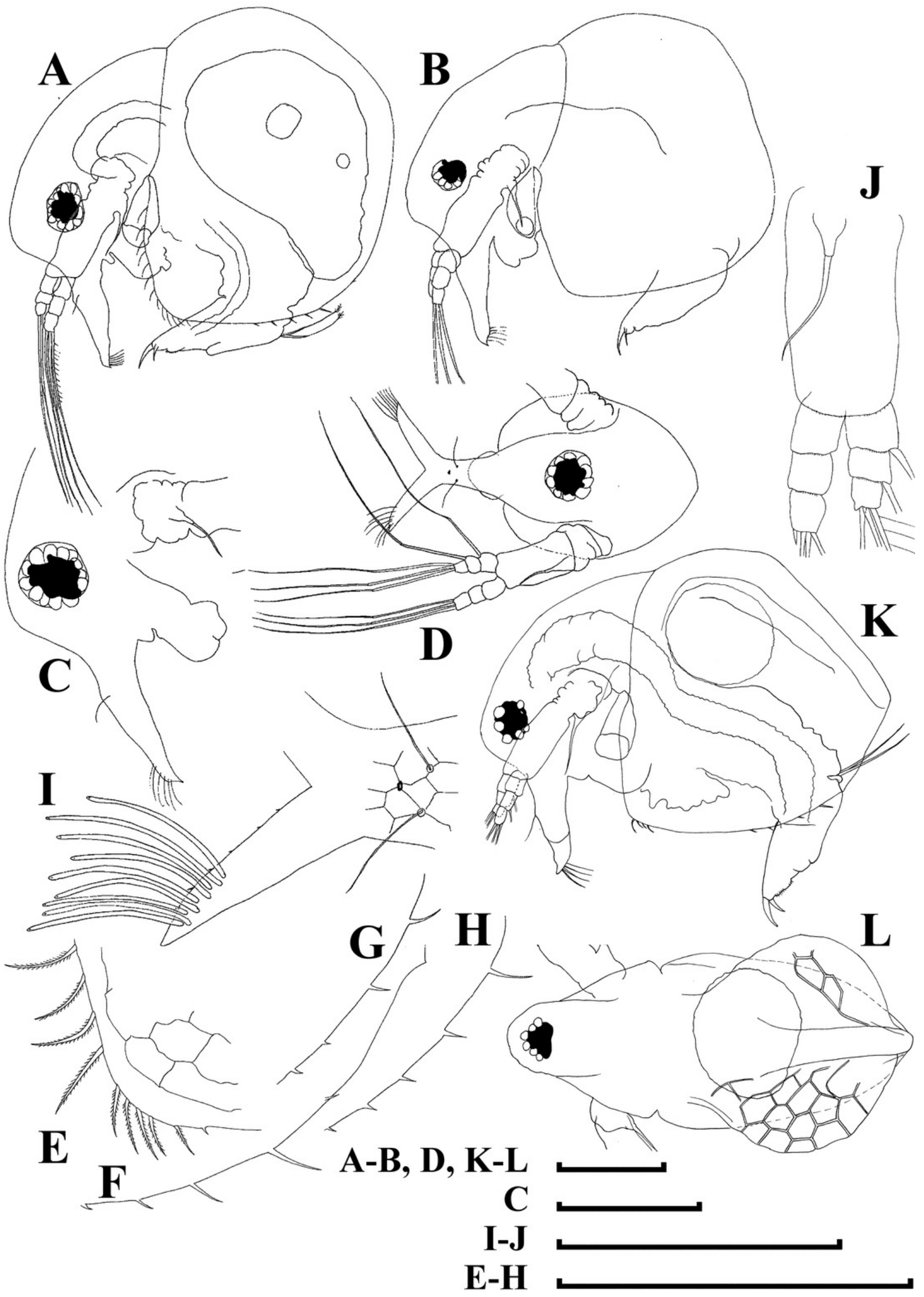




\section{Figure 12}

Bosminopsis zernowi Linko, 1901, parthenogenetic female Ivankovskoe Water Reservoir on Volga River, Tver' Area, European Russia.

A-C, Postabdomen. D, Limb I. E, Ejector hooks I. F, Limb II. G, Distal armature of its gnathobase. H, Limb III. I, Its inner-distal portion. J, Granthobase III. K, Limb IV. L, Its innerdistal portion. M, Limb V. Scale bar $=0.1 \mathrm{~mm}$. 


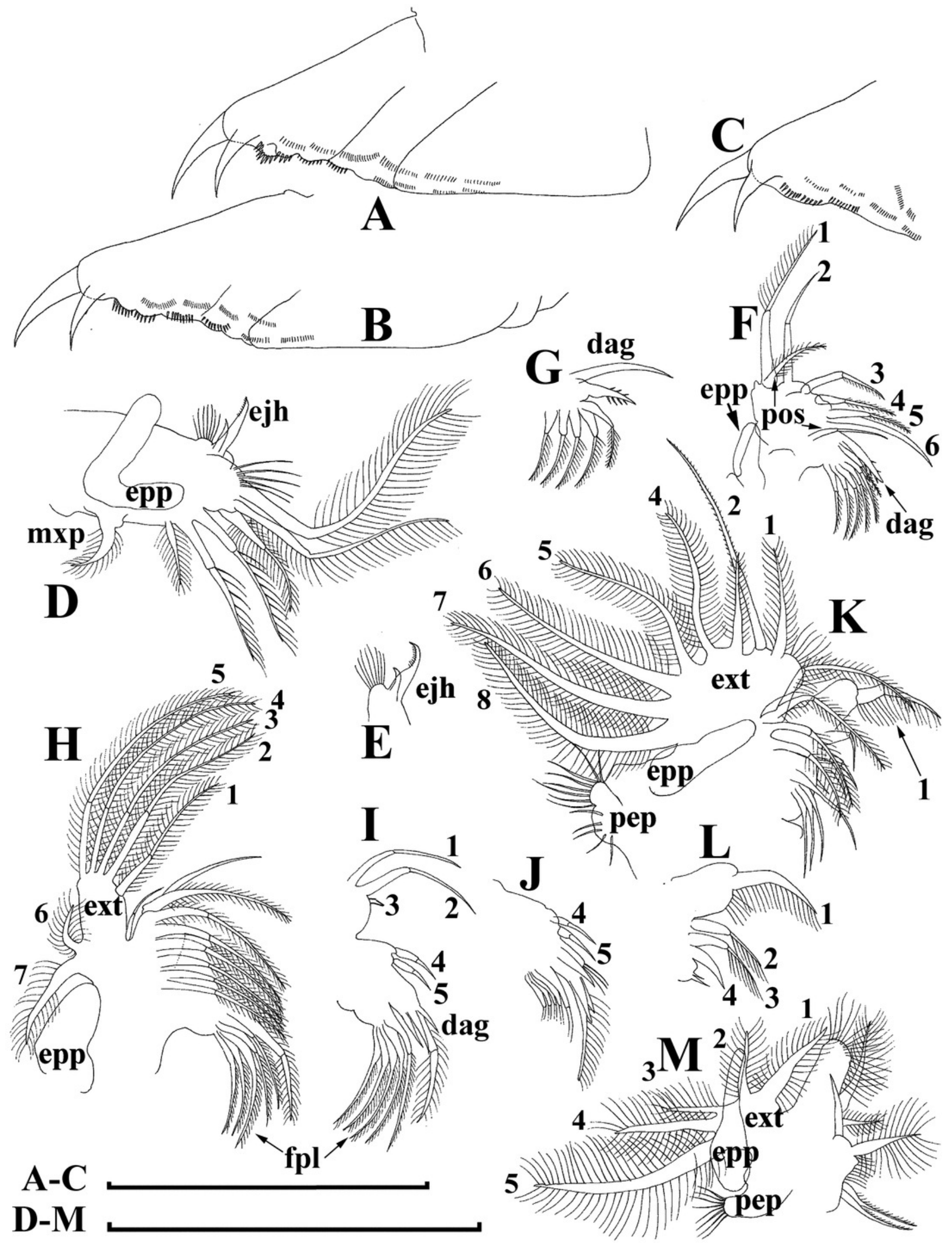




\section{Figure 13}

Bosminopsis zernowi Linko, 1901, juvenile male of instar II (A, C-G, I, K) and instar I (B, $\mathrm{H}$, J) from Lake Livadijskoe, Primorski Territory, Far East of Russia.

A-B, Lateral view. C, Head, lateral view. D, Its anterior view. E, Antero-ventral valve portion.

F-G, Posterior portion of valve. H-I, Postabdomen. J-K, Limb I. Scale bars $=0.1 \mathrm{~mm}$. 


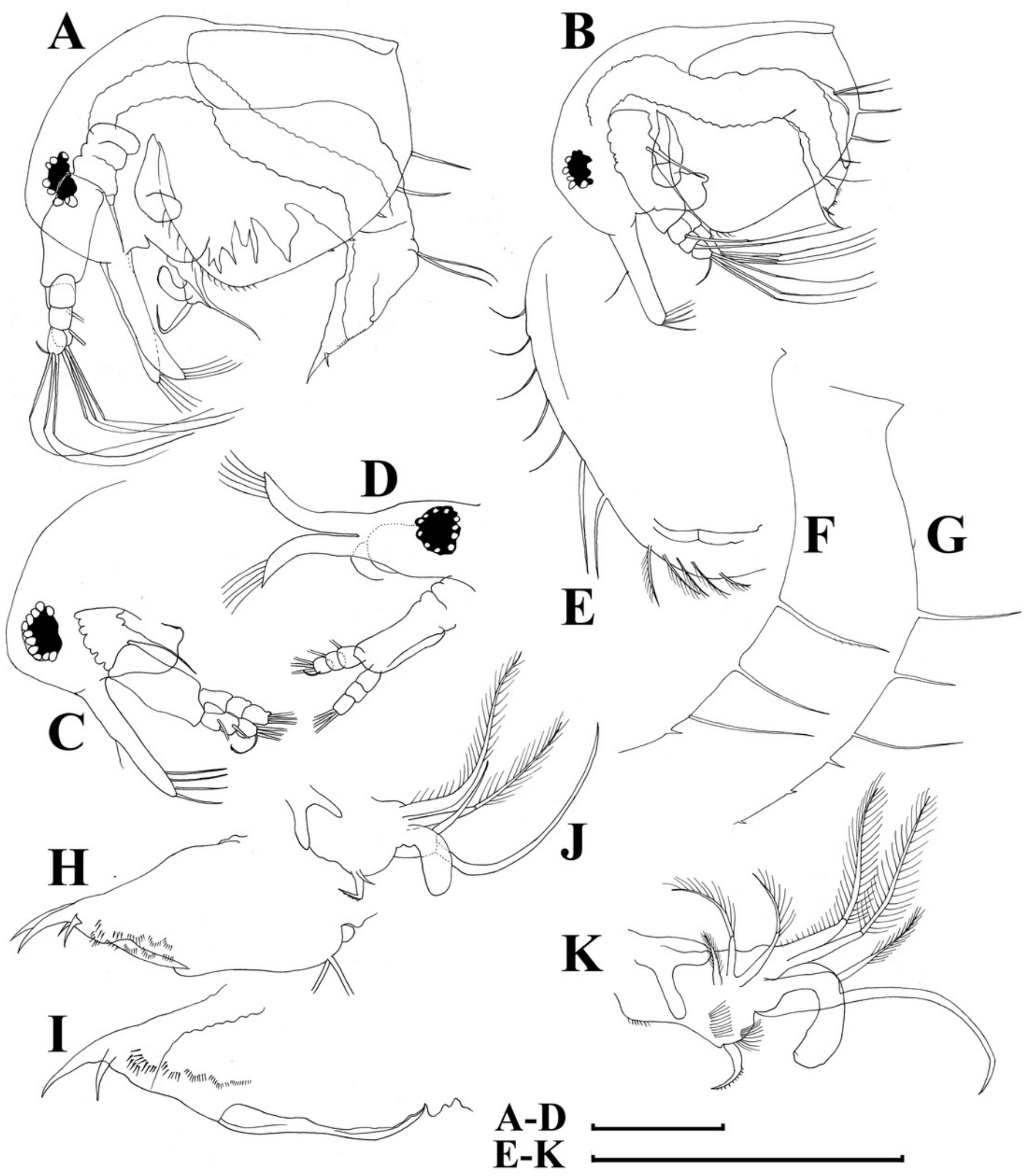




\section{Figure 14}

Bosminopsis zernowi Linko, 1901, adult male from Lake Livadijskoe, Primorski Territory, Far East of Russia.

A, Lateral view. B, Head, lateral view. C, Its anterior view. D, Valve antero-ventral portion. E, Posterior portion of valve. F, Postabdomen. G, Antenna I. H. Antenna II. I, Limb I. Scale bars = $0.1 \mathrm{~mm}$. 


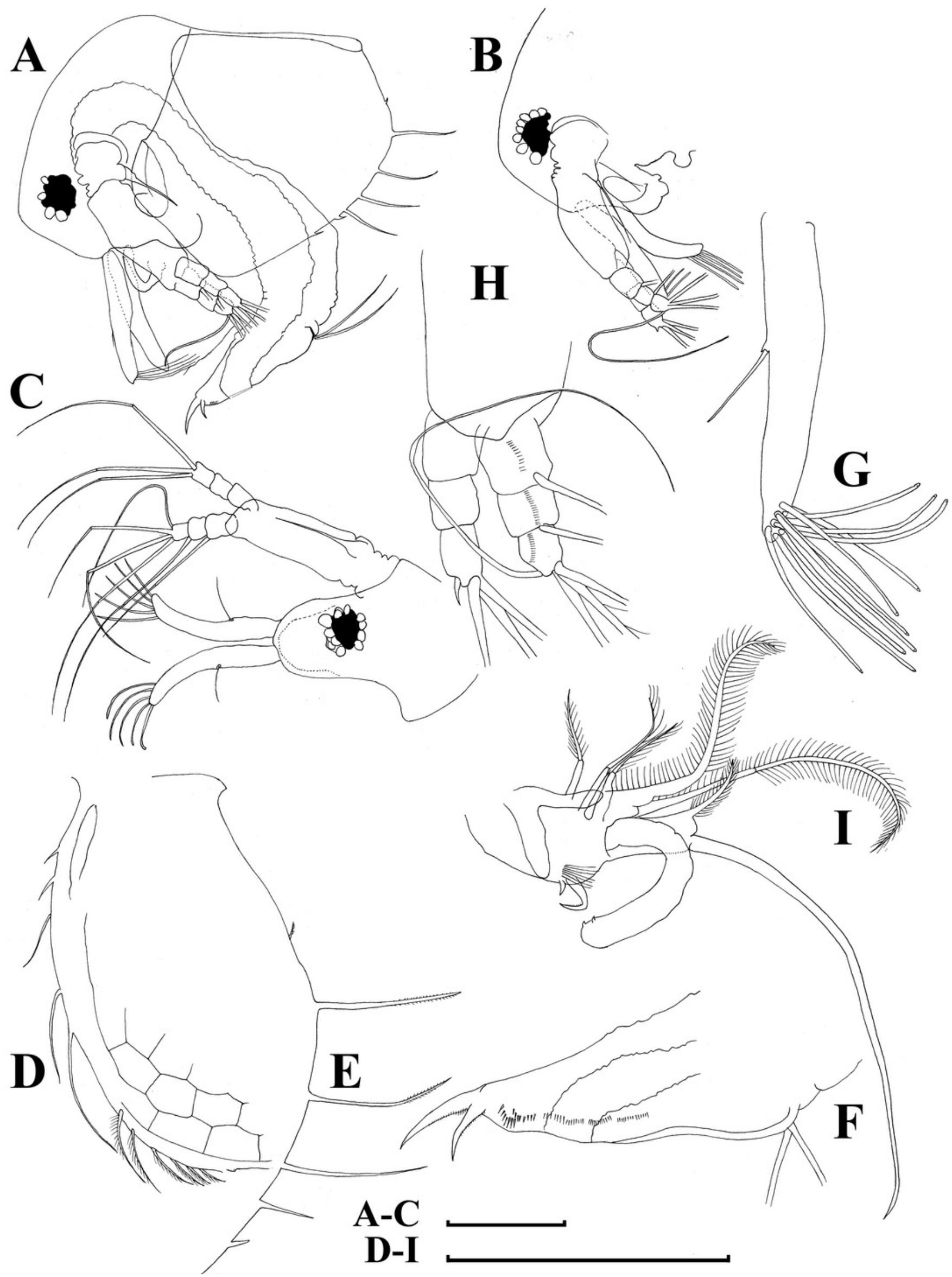

PeerJ reviewing PDF | (2021:01:57215:2:0:NEW 21 Mar 2021) 


\section{Figure 15}

Schematic representation of distribution of two major morphotypes of the juvenile parthenogenetic female: with several mucro-like spines (red) and a single mucro (blue).

Visualisation was made in free software DIVA-GIS7.5.0 https://www.diva-gis.org using free spatial GIS data from http://www.naturalearthdata.com as the layers. Symbols are inserted manually.

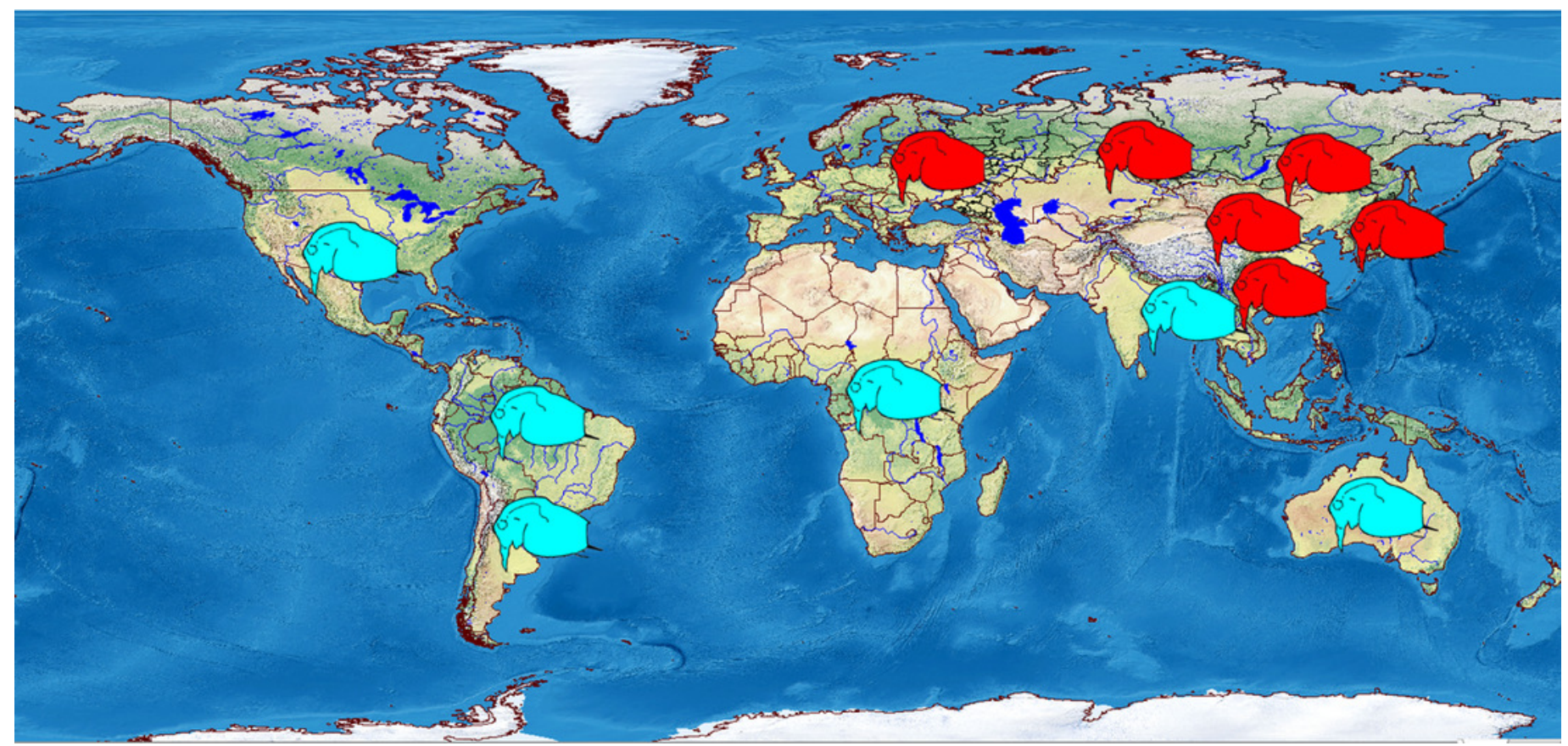




\section{Table $\mathbf{1}$ (on next page)}

Genes, primers and annealing temperatures used in this study of the Bosminopsis deitersi species complex. 


\begin{tabular}{|c|c|c|c|c|c|}
\hline Gene & Primers & Sequence $5^{\prime}-3^{\prime}$ & $\begin{array}{l}\text { Temp. } \\
\left({ }^{\circ} \mathrm{C}\right)\end{array}$ & $\begin{array}{l}\text { Amplico } \\
\text { n } \\
\text { length }\end{array}$ & Reference \\
\hline \multirow[t]{2}{*}{ COI } & COI_Bosm_F & TGTAACAGCTCACGCATTTG & $50-54$ & 415 & This paper \\
\hline & COI_Bosm_R & ACCTGCTAGAACGGGAAGAC & $50-54$ & & This paper \\
\hline \multirow[t]{2}{*}{$16 \mathrm{~S}$} & $16 \mathrm{~S}-\operatorname{ar} 5$ & CGCCTGTTTATC AA AACAT & $46-57$ & $500-506$ & $\begin{array}{l}\text { (Chapco, Kuperus, } \\
\text { \& Litzenberger, } \\
\text { 1999) }\end{array}$ \\
\hline & 16S-br3 & CCGGTCTGAACTCAGATCACGT & $46-57$ & & $\begin{array}{l}\text { (Chapco et al., } \\
\text { 1999) }\end{array}$ \\
\hline \multirow[t]{2}{*}{$18 \mathrm{~S}$} & $18 \mathrm{a} 1$ & CCTAYCTGGTTGATCCTGCCAGT & $52-59$ & 562 & $\begin{array}{l}\text { (Reumont et al., } \\
\text { 2009) }\end{array}$ \\
\hline & $700 \mathrm{R}$ & CGCGGCTGCTGGCACCAGAC & $52-59$ & & $\begin{array}{l}\text { (Reumont et al., } \\
\text { 2009) }\end{array}$ \\
\hline \multirow[t]{2}{*}{$28 \mathrm{~S}$} & D1a & CCCSCGTAAYTTAAGCATAT & $48-50$ & $370-373$ & $\begin{array}{l}\text { (Reumont et al., } \\
\text { 2009) }\end{array}$ \\
\hline & $\mathrm{D} 2 \mathrm{~b} 2$ & CGTACTATTGAACTCTCTCTT & $48-50$ & & $\begin{array}{l}\text { (Reumont et al., } \\
\text { 2009) }\end{array}$ \\
\hline
\end{tabular}




\section{Table 2 (on next page)}

Metrics of genetic diversity from mitochondrial and nuclear loci in Bosminopsis.

$\mathrm{N}$ - number of sequences; $\mathrm{n}$ - total number of sites (excluding sites with gaps or missing data); $\mathrm{S}$ - number of segregating (polymorphic) sites; $\mathrm{Hd}$ - haplotype diversity; $\mathrm{h}$ - number of haplotypes; Pi - nucleotide diversity per site; $\mathrm{k}$ - average number of nucleotide differences; Fs - Fu's neutrality statistic (Fu, 1997) ; D - Tajima D neutrality test (Tajima, 1989), the starsign is indicated statistical significance $\mathrm{P}<0.05$; DemMod - most likely demographic model by DnaSP v. 6 coalescent simulation (PB - population bottleneck, PD - population decline, n/d not defined) based on Theta-W, probability $\mathrm{P}(\mathrm{Sim}<\mathrm{Obs})$ is indicated as a percentage in brackets. 


\begin{tabular}{lllllllllll}
\hline Loci & N & $\mathbf{n}$ & $\mathbf{S}$ & $\mathbf{h}$ & $\mathbf{H d}$ & $\mathbf{P i}$ & $\mathbf{k}$ & $\mathbf{F s}$ & $\mathbf{D}$ & DemMod \\
\hline COI & 16 & 415 & 100 & 2 & 0.125 & 0.038 & 12.5 & 17.06 & $-2.52^{*}$ & PB (4.8) \\
(mit.) & & & & & & & & & & \\
$16 \mathrm{~S}$ & 60 & 500 & 99 & 8 & 0.647 & 0.044 & 23.9 & 26.70 & -0.04 & PD (4.9) \\
(mit.) & & & & & & & & & & \\
$18 \mathrm{~S}$ & 43 & 562 & 6 & 5 & 0.221 & 0.001 & 0.36 & -3.02 & $-2.11^{*}$ & $\mathrm{n} / \mathrm{d}$ \\
(nucl.) & & & & & & & & & & \\
$28 \mathrm{~S}$ & 75 & 377 & 50 & 5 & 0.392 & 0.039 & 14.3 & 26.25 & 0.99 & PB (0.01) \\
(nucl.) & & & & & & & & & & \\
\hline
\end{tabular}

1 


\section{Table 3 (on next page)}

Estimates of evolutionary divergence over sequence pairs between groups.

The number of base differences per site from averaging over all sequence pairs between groups are shown. Standard error estimates are shown above the diagonal and were obtained by a bootstrap procedure (100 replicates). This analysis involved 61 nucleotide $16 S$ sequences. All ambiguous positions were removed for each sequence pair (pairwise deletion option). There was a total of 507 positions in the final dataset. Evolutionary analyses were conducted in MEGA-X (Kumar et al., 2018) . 


\begin{tabular}{lrrrrrrr}
\hline \multicolumn{1}{c}{ Groups } & $\mathbf{1}$ & $\mathbf{2}$ & $\mathbf{3}$ & $\mathbf{4}$ & $\mathbf{5}$ & $\mathbf{6}$ \\
\hline Eurasia & & 0.003 & 0.014 & 0.014 & 0.015 & 0.020 \\
Far East & 0.004 & & 0.014 & 0.014 & 0.015 & 0.020 \\
North America & 0.122 & 0.122 & & 0.014 & 0.017 & 0.021 \\
South America & 0.116 & 0.112 & 0.128 & & 0.012 & 0.019 \\
Thailand & 0.114 & 0.110 & 0.137 & 0.084 & & 0.020 \\
OUT & 0.224 & 0.226 & 0.223 & 0.212 & 0.214 & \\
\hline
\end{tabular}

1 


\section{Table 4 (on next page)}

Results of a molecular clock test using the Maximum Likelihood method.

Null hypothesis of equal evolutionary rate throughout the tree (at a $5 \%$ significance level). TMC - test for molecular clock in MEGA-X (Kumar et al., 2018). Models: JC - Jukes-Cantor, nst=1 (Jukes \& Cantor, 1969); K2 - Kimura 2-parameter, nst=2 (Kimura, 1980); HKY Hasegawa-Kishino-Yano, nst=2 (Hasegawa, Kishino, \& Yano, 1985) ; GTR - general time reversible, nst=6 (Rodriguez, Oliver, Marin, \& Medina, 1990) . Non-uniformity of evolutionary rates among sites may be modeled by using a discrete Gamma distribution $(+G)$ with 5 rate categories and by assuming that a certain fraction of sites are evolutionarily invariable $(+\mathrm{l})$. 


\begin{tabular}{lllll}
\hline Locus & Substitution model & TMC: & TMC: & Null \\
& in MEGA-X & with clock (lnL) & without clock (lnL) & \\
\hline COI (mit.) & HKY+I & -1154.9 & -1152.1 & Not rejected \\
$1 \mathrm{st}+$ 2nd+3th & & & & Not rejected \\
$16 \mathrm{~S}$ (mit.) & GTR+G & -1588.4 & -1582.1 & Not rejected \\
$18 \mathrm{~S}$ (nucl.) & $\mathrm{JC}$ & -1034.8 & -1033.1 & Not rejected \\
\hline
\end{tabular}

1 